\title{
Ze Stanisławem Soldenhoffem rozmawiaja Michał Rydlewski, Tomasz Siwiec i Radosław Wiśniewski ${ }^{1}$
}

\begin{abstract}
„Ruch Filozoficzny": Panie Profesorze, prosiliśmy o spotkanie, ponieważ odczuwamy niedosyt opowieści, które przytaczał Pan w trakcie zajęć prowadzonych dla stuchaczy studiów doktoranckich w Instytucie Filozofii Uniwersytetu Mikołaja Kopernika w Toruniu. Były to niezwykle ciekawe historie.

Stanisław Soldenhoff: To dlatego, że czasy były ciekawe. Mam rzeczywiście bardzo wiele do opowiedzenia na temat tego, co widziałem i z czym się miałem okazję spotkać. Muszę jednak wtrącić małe sprostowanie. Nie jestem profesorem, ale docentem. Kiedyś przysługiwał mi wprawdzie tytuł "obywatela profesora”, ale "to se ne wrati”.

RF: Jak wspomina Pan okres dzieciństwa? Czy pamięta Pan Profesor jakieś pierwsze ważne przeżycie z tamtego okresu?

S. Soldenhoff: Urodziłem się w Poznaniu i pozostawałem w nim aż do czasu wybuchu wojny. Poznań był wówczas zamożnym miastem. Jako dziecko nie miałem okazji zetknąć się z wielkimi kontrastami społecznymi, z przepaścią między bogatymi a biednymi, które później zwalały mnie dosłownie z nóg, zwłaszcza gdy znalazłem się w Kongresówce. Mój ojciec był pracownikiem w firmie ubezpieczeniowej „Vesta" $^{2}$. Po wojnie dowiedziałem się, że owa firma była przykrywką dla polskiego wywiadu. Mój stryj, czyli brat ojca, był natomiast przed wojną zawodowym oficerem ${ }^{3}$. Pracował w Warszawie, w sztabie generalnym. Bardzo lubiłem spacerować z nim po mieście, ponieważ bardzo impono-
\end{abstract}

J. W. Goethe, Faust, przeł. A. Pomorski, Warszawa, Wydawnictwo Świat Książki, Warszawa 2006, s. 108. („Du nennst mich Herr Baron, so ist die Sache Gut”).

1 Rozmowa odbyła się na początku listopada 2009 roku w toruńskim mieszkaniu Stanisława Soldenhoffa. Tekst stanowi zapis prawie sześciogodzinnej rozmowy. Przeprowadzających ją oznaczono w tekście jako „Ruch Filozoficzny”, a dalej jako "RF”.

2 Bank Wzajemnych Ubezpieczeń „Vesta” został założony w Poznaniu w 1873 roku. Była to druga z kolei firma ubezpieczeniowa powstała na ziemiach polskich. W 1936 roku „Vesta” wybudowała w Poznaniu dla swoich pracowników osiedla mieszkaniowe.

3 Mowa o Kazimierzu Soldenhoffie (1894-1938), dyplomowanym pułkowniku Wojska Polskiego, kawalerze między innymi orderów Virtuti Militari, Krzyża Walecznych oraz Krzyża Niepodległości. 
wało mi, kiedy wojskowi oddawali mu honory, salutując. Pamiętam, że odwiedził nas w 1938, czyli rok przed wojną. Dobiegały mnie wówczas strzępy jego rozmowy z moim ojcem. Stryj był bardzo zdenerwowany. Opowiadał o swojej wizycie w Gdyni. Ja natomiast, już jako młody człowiek, interesowałem się bardzo mocno polityką. Zresztą młodzież w Poznaniu była wyraźnie upolityczniana od najmłodszych lat, zwłaszcza $\mathrm{w}$ duchu endecji. Zorientowałem się wówczas, że stryj wraca z podróży służbowej i że wpadło mu do rąk coś, co wpaść nie powinno. Mówił pośpiesznie, że musi napisać raport, że wie coś na temat jakiejś strasznej sprawy. Kilka dni po tej wizycie dostaliśmy telefon z Warszawy, że stryj nie żyje. Wytłumaczenie okoliczności zgonu wydawało się nam dość absurdalne. Mianowicie na przyjęciu, na którym stryj był razem z żona, zrobiło mu się słabo. Kilkanaście minut później zasłabł i zmarł. Było to wysoce zagadkowe, ponieważ mój stryj był okazem zdrowia. W czasie wojny, zupełnie przypadkowo, dowiedziałem się prawdy na temat faktycznych okoliczności śmierci mego stryja. Mieszkałem wtedy w Nieznanicach, w pięknym majątku, niedaleko Częstochowy. Znajdował się tam pusty pałac, przez który przewijało się grono niezwykle interesujących ludzi, najczęściej ukrywającymi się przed Niemcami ${ }^{4}$. Pewnego dnia zjawił się tajemniczy pan, którego moja mama szybko jednak zdemaskowała. Pamiętam jak powiedziała mi: „To zawodowy oficer. Widzę to po jego ruchach". Zacząłem towarzyszyć temu człowiekowi $\mathrm{w}$ długich, wieczornych spacerach. Na jednym z nich powiedział do mnie: "Słuchaj Stachu, uważam ciebie za dorosłego człowieka i dlatego chcę się o coś zapytać. Czy pułkownik Kazimierz Soldenhoff był twoim krewnym?”. „Tak, to był mój stryj” - odpowiedziałem. Odrzekł mi wówczas: „Twój stryj nie umarł naturalną śmiercia, lecz został otruty przez Abwehrę, ponieważ wykrył jakąś aferę na wybrzeżu".

RF: W 1938 roku miat Pan 10 lat. Czy pamięta Pan Profesor jakieś wypowiedzi, nastroje społeczne odnoszace się do zmarłego 3 lata wcześniej marszałka Józefa Piłsudskiego?

S. Soldenhoff: Dość trudno mi jest o tym mówić, ponieważ niewiele pamiętam. Wiem, że ojciec nie był piłsudczykiem. Pochodził z Kongresówki i był powstańcem wielkopolskim, za udział w którym otrzymał stopień oficerski. Jako zastępca dowódcy kompanii i świeżo upieczony porucznik brał także udział w walkach o Lwów, za co został odznaczony orderem Virtuti Militari ${ }^{5}$. Gestapo aresztowało mego ojca dnia 1

4 Pałac w Niznanicach (pow. częstochowski) został wybudowany w 1918 roku przez ówczesnego właściciela majątku Aureliusza Wünsche, polaka niemieckiego pochodzenia. Rodzina Wünsche była właścicielem nieznanieckiego pałacu do 1946 roku.

5 Maksymilian Soldenhoff (1980-1939) został rozstrzelany przez Niemców w Forcie VII w Poznaniu. Jego symboliczne miejsce spoczynku znajduje się na warszawskich Powązkach, w rodzinnym grobowcu Soldenhoffów. 
listopada 1939 roku. Po moją matkę, moje rodzeństwo i mnie samego - a miałem wtedy 11 lat - przyszli dokładnie tydzień później. W brutalnym tonie oznajmili, że mamy się spakować w ciągu piętnastu minut. Zachowywali się nadzwyczaj bezczelnie, wręcz bandycko. Najpierw pojechaliśmy na komendę policji. Pamiętam listopadową mżawkę tamtej nocy i grupy wysiedlanych ludzi, w przeważającej mierze kobiet i dzieci. Mój brat miał wtedy 15 lat, a siostra około dwudziestu, ja natomiast byłem najmłodszy. Następnie zostaliśmy wywiezieni do zorganizowanego naprędce obozu. To właśnie tam po raz pierwszy zetknąłem się $\mathrm{z}$ bestialstwem hitlerowców. Wszędzie słychać było tylko krzyki i odgłosy bicia. Słowem: eksplozja nienawiści. Pamiętam, że nie wiedzieliśmy, gdzie dokładnie jesteśmy. Wiadomo było jedynie, że gdzieś w okolicach Poznania. Dokoła były tylko druty kolczaste, podwójny płot i wieże strażnicze. Później okazało się, że były to budynki magazynów amunicji, które Niemcy przejęli. Tam też zaczęto tworzyć obóz przejściowy dla ludzi wysiedlanych z Poznania. Na pierwszy ogień poszły oczywiście rodziny powstańców wielkopolskich. Hitlerowcy wpakowali nas do budynku bez światła. Wyobraźcie sobie listopadowa, zimną noc i płacz tych dzieciaków - zmarzniętych, głodnych, wystraszonych; wyrwanych z normalnego, ludzkiego trybu życia. Leżeliśmy na betonie. Po pewnym czasie przyszli jacyś Niemcy i zaczęli z nami rozmawiać. Moja mama znała świetnie język niemiecki i zaczęła się im żalić. Tłumaczyła, że nie rozumiemy przyczyny naszego zatrzymania, że nie wiemy gdzie jesteśmy i jaki jest cel naszego pobytu w obozie. Wtedy zobaczyłem u Niemców pewne poruszenie, jakąś wewnętrzną dezaprobatę dla tak bestialskich działań. Poszli i po około trzydziestu minutach wrócili z kocami, chlebem i gorącą kawą zbożową w wiadrach. Przeżyłem wówczas pouczające doświadczenie, że istnieją różni Niemcy: że są Niemcy-bestie, Niemcy-kanalie, ale są też wśród nich ludzie wrażliwi i czuli na krzywdę innych. To doświadczenie uodporniło mnie przed uleganiem stereotypom, przed bezmyślnym uogólnianiem cech innych narodów. Nie pamiętam, czy na wykładach opowiadałem wam o moim spotkaniu z ludobójcą. Mówiłem wam o tym?

RF: Nie, Panie Profesorze...

S. Soldenhoff: Jest to jedno z moich ostrych - że się tak wyrażę - wspomnień z czasów wojny. Pamiętam, jak mama wysłała mnie do magazyniera $\mathrm{w}$ jakiejś sprawie. Wyszedłem na podwórze majątku i zauważyłem jakichś nowych Niemców. Dostrzegłem też owego magazyniera, który rozmawiał z oficerem tychże nowicjuszy. Podszedłem grzecznie, mówię: „Guten Tag”, na co ten oficer uśmiechnął się i odpowiedział równie grzecznie na powitanie. Było to moje jedyne intuicjonistyczne przeżycie, które okazało się trafne. A do intuicji mam stosunek dość sceptyczny. W każdym razie świetnie pamiętam, że kiedy ten oficer na mnie spojrzał, to poczułem, że mi nogi miękna, że tracę władzę nad 
własnym ciałem. Rozmowa była dość zdawkowa, załatwiłem sprawę z magazynierem - przy czym oficer zachowywał się bardzo spokojnie i kulturalnie. Kiedy wracałem do pałacu spotkałem mojego kolegę. Józio oznajmił mi, że mamy gości. Na co odrzekłem, że już o tym wiem. „A wiesz kim oni są? Oni są z Einsatzgruppe" - poinformował mnie. Wtedy jeszcze nie znałem tego terminu, zapoznałem się z nim po wojnie, z filmów dokumentalnych i literatury. Teraz wiem, że Einsatzgruppe to były oddziały egzekucyjne, które zajmowały się tylko mordowaniem ludzi. Powołał je Heinrich Himmler po napaści na Związek Radziecki głównie w celu likwidowania Żydów, ale także jeńców radzieckich, oficerów Armii Czerwonej, a także Polaków. Już wtedy Józiu powiedział mi: „Słuchaj, każdy z nich ma tysiące ludzi na sumieniu. Oni zajmują się tylko rozstrzeliwaniami. To jest ich zawód!".

RF: Do którego roku przebywat Pan Profesor w majątku w Nieznanicach?

S. Soldenhoff: Aż do czasu wyzwolenia przez Armię Radziecka, czyli do 17 stycznia 1945 roku. Często jednak przebywałem również w Warszawie.

RF: Jak wspomina Pan moment wkroczenia Armii Czerwonej?

S. Soldenhoff: Niemcy, którzy kwaterowali w pałacu od sierpnia 1944 roku, wyjechali dwa dni przed wkroczeniem Rosjan, ponieważ wiedzieli już, że front się załamał. Znamienne, że chcieli nas ze sobą zabrać. Pamiętam, że przyszły do nas dwie Niemki, które były razem z tymi oficerami, obudziły mamę i mówiły, aby zabrać się z nimi, bo niebawem przyjdą Rosjanie i będzie jeden wielki bałagan. Ale gdzie nam uciekać z Niemcami? To choćby ze względów psychologicznych było niemożliwe. Wejście Rosjan to $\mathrm{w}$ zasadzie temat na osobną opowieść. Przez dwa dni ziemie były niczyje: Niemcy uciekli, a Rosjan jeszcze nie było. Spotkanie z Armią Czerwoną było dla mnie doznaniem ambiwalentnym. Pierwsze pancerne jednostki robiły ogromne wrażenie. Ludzie witali Rosjan z radością, zapraszali ich do domów na poczęstunek, dawali papierosy lub wódkę na rozgrzanie, bo mróz był bardzo ostry. Ale Rosjan interesowało jedno, pytali tylko: „Gdzie są Niemcy?”. To była waleczność rzucająca się w oczy, doskonałe wojsko. Wtedy pojąłem dlaczego Wermacht tak szybko uciekł. Ale po kilku godzinach ten obraz, uległ zmianie. Nadciągnęła zgraja, w żaden sposób nieuformowana. Wszyscy byli pijani. Zachowywali się jak przysłowiowi Hunowie, zaczynając od bezmyślnego niszczenia mienia i dobytku ludzi. Wyprowadzili, na przykład, cały inwentarz, to znaczy krowy, konie, owce na zewnątrz, a następnie wszystko wystrzelali. Całkowicie bez sensu. Mieliśmy w parku pszczoły, to proszę sobie wyobrazić, że rozwalili nawet te ule. Wtedy pierwszy i ostatni raz w życiu widziałem pszczoły latające po śniegu. Cały majątek w ciągu kilku godzin został doprowadzony do ruiny, co bynajmniej nie przeszkadzała im nazywać nas przyjaźnie „sojusznikami". 
RF: Wspomniat Pan Profesor, że po aresztowaniu przebywat wraz z matka i rodzeństwem w obozie przejściowym. Pomimo grozy całej sytuacji, Pańska uwaga byt zaprzątnięta czymś zgoła innym.

S. Soldenhoff: To prawda! Jak mówiłem wysiedlili nas 9 listopada 1939 roku. Niemcy przyszli do domu o jedenastej wieczorem i powiedzieli krótko „raus!”. Wieźli nas z komendy policji w nieznanym kierunku. Mokliśmy w tym listopadowym deszczyku, ponieważ ciężarówka nie miała plandeki. Nagle wśród aresztowanych ludzi wybuchła panika, ponieważ samochód niespodziewanie się zatrzymał. Okazało się, że utknęliśmy w korku. Naprzeciwko nas stanął transport niemieckiego wojska, w wyniku czego doszło do kłótni między naszą eskortą a żołnierzami z Wermachtu. Słychać było, że strasznie się o coś spierali. Któraś z pań krzyknęła, że wiozą nas na rozstrzelanie, ludzie zaczęli krzyczeć i panikować. Słychać było modlitwy i litanie, wszyscy myśleli, że są to ich ostatnie chwile życia. A wiecie co mnie najbardziej interesowało? Z jakiej broni będą do nas strzelać! Od dziecka bardzo interesowałem się bronią. Wiedziałem, jakimi karabinami dysponują Niemcy i to właśnie ta kwestia zajmowała mnie wówczas najmocniej. Przy okazji chciałbym od razu dodać, że obiegowa opinia, jakoby dzieci walczyły $\mathrm{z}$ bronią $\mathrm{w}$ ręku w szeregach AK jest naciągana. Zdarzały się wprawdzie przypadki, że partyzanci przygarniali do lasu osierocone dzieciaki, ale teza, że następnie walczyły one w partyzantce $\mathrm{z}$ Niemcami jest bujdą. Naturalnie dzieci w Powstaniu Warszawskim wykorzystywane były jako łącznicy, ale nic ponad to. Jak chcecie to mogę wam pokazać zdjęcia, na których miałem dwanaście lub trzynaście lat, jestem tam na nich $\mathrm{w}$ hełmie niemieckim, z niemieckim karabinem i pasem, ale te zdjęcia robili mi sami Niemcy w ramach zabawy! Nie mniej przed żołnierzami Powstania Warszawskiego należy ściągać czapki z głów. Proszę sobie ich wyobrazić: okupowani i zmęczeni doświadczeniami wojny, słabo uzbrojeni, byli w ogromnej mniejszości, a ich waleczność była czymś zupełnie wyjątkowym w historii Polski. Tak długo i tak ofiarnie walczyli przecież z najnowocześniejszą wówczas armią świata. Czytałem kiedyś „Pamiętniki” Tadeusza Bora-Komorowskiego, który próbował bronić się przed krytyką decyzji o rozpoczęciu powstania, decyzją na której suchej nitki nie zostawił generał Władysław Anders. Anders był oburzony, że podjęto tak bezmyślna, $\mathrm{w}$ jego przekonaniu, decyzję, gdy wiadomo było, że na Armię Czerwoną nie można liczyć. Natomiast odwaga powstańców jest przepiękną kartą naszej historii. Dlaczego oni byli tacy waleczni? Dziś twierdzi się, że wychowywano ich w duchu patrioty$\mathrm{zmu}$, co nie do końca jest, moim zdaniem, prawdą. Ja zresztą dobrze pamiętam to wychowanie, bo sam mu podlegałem. Rzeczywiście, zarówno w domu jak i w szkole kładziono duży nacisk na patriotyzm i nieustannie ustawiano nas - zwłaszcza przed wybuchem wojny - antyniemiecko. Jako dziesięcioletni chłopcy chodziliśmy wybijać szyby w niemieckich 
sklepach. Sam pamiętam, jak rąbnąłem kiedyś kamieniem w szybę niemieckiej księgarni. W moim przekonaniu jednak u powstańców przede wszystkim zadziałał kilkuletni wpływ okupacji. Oni po prostu chcieli się odgryźć na Niemcach za ich łajdactwa; za to, że przez lata wojny musieli patrzeć bezradnie na śmierć członków swoich rodzin, na śmierć rodaków, śmierć sąsiadów i przyjaciół. Przede wszystkim młodzież rwała się do walki, bo chciała dopaść tych morderców i to, jak myślę, był główny powód tak wielkiej mobilizacji Warszawiaków.

RF: Panie Profesorze pamiętamy, że na naszym seminarium opowiadat Pan wstrzasajaca historię rozstrzelania przez nazistów matych dzieci cygańskich.

S. Soldenhoff: Tak, to najbardziej koszmarne wspomnienie z czasów wojny. Jechałem wówczas do Warszawy pociągiem pasażerskim - przepełnionym, jak zwykle w Generalnej Guberni. To był czerwiec, piękny letni dzień. Zatrzymaliśmy się niedaleko Piotrkowa. Kolejarze poinformowali nas, że nie wiedzą kiedy ruszymy dalej, ponieważ pierwszeństwo miały transporty wojska na front wschodni. Obok naszego pociaggu czekał też pułk SS-manów. Tuż przy stacyjce kolejowej, zaraz przy torach, była piękna łączka, na której bawiły się cygańskie dzieci. Dziewczynki i chłopcy nie miały więcej niż 10 lat, ale jak wiecie Niemcy traktowali Cyganów tak samo, jak Żydów. Dla nazistów byli to po prostu podludzie, których trzeba likwidować. Nagle nadjechała dwukonna bryka z czterema grubymi żandarmami. Od razu zauważyłem, że jadą na polowanie, ponieważ w rękach trzymali dubeltówki. Zobaczyli te Cyganiątka, zsiedli z bryczki i z takim obrzydliwym rechotem zaczęli strzelać z dubeltówek do tych dzieciaków. Trwało to kilka minut. Wszystkie dzieci wymordowali. Myśmy w pociągu zamarli ze zgrozy. Pamiętam krzyki tych dzieci, ich przerażenie w oczach. Powiem wam, że to bestialstwo do dziś często mi się śni. To wspomnienie jest nie do zatarcia. A co ciekawe, w Poznaniu byłem wychowywany w duchu antycygańskim. Mówiono, że to podejrzane towarzystwo, że należy omijać ich tabory, ponieważ Cyganie porywają polskie, katolickie dzieci. Już od dzieciństwa miałem zakodowaną jakąś niechęć do Cyganów. Ale nie mam wątpliwości, że gdyby nie ten transport SS-manów, stojący obok, to ci ludzie z pociągu ruszyliby na tych żandarmów i rozszarpali ich na strzępy. Zapadła cisza. Byliśmy tym widokiem sparaliżowani i to było właśnie najgorsze podczas wojny, że człowiek patrzył na bestialstwo, ale nie był w stanie nic zrobić. To mogło sprawiać wrażenie obojętności, ale to nie była obojętność, lecz bezsilność. Widziałem kilkadziesiąt transportów do Treblinki, widziałem Holocaust na własne oczy, ale nie chcę mówić o nim w sposób uogólniający. Nie wiem szczegółowo, jak wyglądał Holocaust na terenie wschodniej Polski, tam gdzie urzędowali bolszewicy po 17 września, ale z tego, co wiem, dochodziło tam do kolaboracji części Żydów z NKWD, a Polacy po inwazji niemieckiej na Rosję, zaczęli się później na owych Żydach mścić. Wierzę w to, że w Jedwab- 
nem jakaś grupa Polaków pomagała Niemcom, ponieważ właśnie na tych terenach miały miejsce porachunki polsko-żydowskie. Natomiast bzdura jest twierdzenie, że to była polska inicjatywa i że to myśmy zaczęli. Wszędzie działo się to samo, przyjeżdżało Sonderkommando, które mordowało Żydów na miejscu, albo wywoziło do gett w większych miastach. Jedyny udział Polaków w mordowaniu Żydów, jaki widziałem na własne oczy, a który dziś jest przemilczany, to udział w Holocauście Policji Granatowej Generalnego Gubernatorstwa. Na terenie Generalnej Guberni podlegali oni Niemcom. Policja Granatowa była formacją pomocnicza, zaopatrzoną $\mathrm{w}$ broń; $\mathrm{w}$ miastach posiadali pistolety, na terenach wiejskich karabiny. Policja pomagała Niemcom w łapankach, a potem w mordowaniu Żydów, co dla mnie jest faktem bezspornym. Nie da się tego wymazać z historii. Pamiętam nawet do dziś nazwiska Polaków z Policji Granatowej, którzy zabijali Żydów, nawet z własnej inicjatywy. Bo jeśli dostawali rozkazy niemieckie, aby zlikwidować jakiegoś Żyda, czy jaką́ grupkę w lesie, to mogli przecież kazać im uciekać, gdzie pieprz rośnie. Nikt by tego nie sprawdził, bo Niemcy mordowali za dużo Żydów, aby sprawdzać, czy polski policjant wykonał ich rozkaz, czy nie. Oni się jednak w to angażowali, co było draństwem. Podobnie jak zaangażowali się $\mathrm{w}$ akcje antypartyzanckie, jeżdżąc razem z Niemcami do walki z polskimi żołnierzami, co również widziałem na własne oczy. Nie rozumiem tych Żydów, którzy nas nienawidzą. Uważają oni, że byliśmy obojętni, ponieważ przyglądaliśmy się Holocaustowi, nic nie robiąc. Ale ta pozorna obojętność wynikała z beznadziejności sytuacji. Podam jeden przykład, pamiętam jak jechałem raz rowerem na tajne lekcje, upał straszny, pod wiaduktem, na torach, stoi transport z Żydami z Częstochowy. Słychać jeden wielki skowyt z tych wagonów: „Wody! Wody! Wody!”. Nie miałem żadnej możliwości pomocy, ponieważ eskorta była nieprawdopodobnie silnie uzbrojona. Nie wolno było podchodzić na kilkanaście metrów, gdyż strzelano bez ostrzeżenia. Z wiaduktu zauważyłem, jak wyrzucano zwłoki dzieci, które w tym upale zdążyły się już podusić. To również mi się często śni. Podobnych sytuacji były tysiące, kiedy na naszych oczach działy się potworności, a nie można było pomóc. Oczywiście można było demonstracyjnie zaprotestować, ale to by nic nie dało, poza samobójstwem. A Amerykanie zarzucają nam, że Polacy popierali wręcz takie potworności. Naprawdę nie wiem, skąd się biorą takie bzdury. Były jednostki, które mówiły: „Hitler przycisnął Żydków, po wojnie trzeba będzie postawić mu pomnik", ale to był absolutny margines i takich łajdaków ludzie zaraz uciszali. Powszechnym uczuciem było współczucie. Ujawniało się ono w takim powiedzeniu: „Dzisiaj Żydzi, jutro my”. Polacy zdawali sobie sprawę, że są następni w kolejce do zagłady. Wokół Holocaustu są potworne zakłamania, a największym $\mathrm{z}$ nich jest przemilczanie bezspornego faktu, że przygniatającą większość Żydów, którzy zginęli w Holocauście, 
stanowił żydowski proletariat. Mordowano przede wszystkim biedotę żydowska, bo tak na dobrą sprawę, to innych Żydów w Polsce nie było. Te legendy o bogatych Żydach, posiadających ogromne majątki i kamienice, to wielka przesada. Bogaci, żydowscy fabrykanci, finansiści, właściciele majątków, to były jednostki, ułamek procenta całej zbiorowości żydowskiej w Polsce. Oni zdążyli uciec przed Hitlerem dużo wcześniej, zresztą bardzo rozsądnie.

RF: Panie Profesorze, jaki wptyw na pańskie poglady miała wojna? Po wojnie interesowat się Pan filozofia zła. Czy inspiracja, aby zajmować się ta problematyka, były doświadczenia wojenne?

S. Soldenhoff: Byłem wychowywany w rodzinie bardzo katolickiej, zwłaszcza moja mama była osobą bardzo wierzącą. Po wojnie nie mogła się pogodzić z tym, że odszedłem od Kościoła. W dzieciństwie, zwłaszcza w czasie wojny, byłem bardzo wierzący. Zresztą jeszcze po wojnie byłem ministrantem. Jednak wojna, a ściślej mówiąc wspomnienia wojenne, stopniowo oddalały mnie od katolicyzmu. Wspomnienia te stale wracały i to pytanie, gdzie był Pan Bóg, kiedy mordowano dzieci? Owo pytanie stawiałem sobie nie tylko ja, ale też ci prześladowani, mordowani i świadkowie zbrodni. To gryzło mnie najbardziej. Szukałem pomocy u księży, jakiejś próby odpowiedzi na to pytanie. Żaden z nich nie potrafił udzielić mi satysfakcjonującej odpowiedzi. Mówili mętnie, że to dla nas ludzi niepojęte, że nie potrafimy odgadnąć zamiarów Boga itp. Jak może być niepojęta kwestia mordowania dzieci? Jest to absolutne draństwo i obojętność wobec tego draństwa jest czymś niezrozumiałym.

RF: Co skłoniło Pana Profesora, by po wojnie, w 1945 roku przenieść się do Torunia?

S. Soldenhoff: Mieliśmy rodzinę w Toruniu. Mama miała bardzo liczne rodzeństwo. W sumie to chyba było ich czternaścioro. Tak samo, jak ojciec mojej żony - rasowy inżynier, a jednocześnie humanista, który znał grekę i łacinę. Jego rodzeństwo liczyło siedemnaście osób. Początkowo chcieliśmy wrócić do Poznania, ale w 1945 roku tam ciągle trwały walki. Samo oblężenie tego miasta trwało kilka tygodni. Na domiar złego, nasze mieszkanie w Poznaniu zostało niemalże zniszczone od uderzeń pocisków artyleryjskich. Brat jednak wybrał się tam na te nasze poznańskie śmieci $\mathrm{i}$ - rzecz ciekawa - w tym mocno nadpalonym mieszkaniu znalazł naszą przedwojenną szafkę, a w niej dokumenty i różne albumy fotograficzne. Nie wiemy dokładnie, jacy Niemcy zajmowali nasze mieszkanie po wysiedleniu, ale jesteśmy im wdzięczni, że te dokumenty i pamiątki odłożyli, że nie przyszło im do głowy, by je zniszczyć. Dzięki temu odzyskaliśmy wszystko, włącznie z dyplomem orderu Virtuti Militari ojca. W Toruniu zdałem egzamin do gimnazjum, potem zacząłem uczęszczać do liceum im. Królowej Jadwigi. Co ciekawe, było to liceum żeńskie. Nas chłopców było tylko ośmiu. Liceum zakończyłem zdaniem matury. W tym czasie byłem też ministrantem. 
Po zdaniu matury nie chciałem pozostawać na garnuszku cioci, u której mieszkałem, zatem zacząłem rozglądać się za jakąś pracą. Ale jednocześnie chciałem studiować. Marzyło mi się leśnictwo, ponieważ od najmłodszych lat ciągnęło mnie do lasu i przyrody. Pamiętam, że od dziecka najlepiej czułem się na wsi. Wyjazdy na wieś zawsze były dla mnie wielkim świętem. Lecz na leśnictwo nie było siły. Mógłbym wprawdzie zacząć je w Poznaniu, ale tych studiów nie połączyłbym z pracą z uwagi na wielość przedmiotów ścisłych oraz uczestnictwo w laboratoriach. Pozostawał Toruń. Zacząłem więc myśleć, jak pogodzić studia z zarabianiem na życie i po namyśle wybrałem prawo, które w Toruniu było dość rozbudowane. Kłopot $w$ tym, że prawo mnie nie interesowało. Podjąłem jednak ten kierunek na studiach dziennych magisterskich, a oprócz tego bardzo ciężko pracowałem. To zabawna historia, gdyż pół roku po maturze zostałem "profesorem”, a dokładnie „obywatelem profesorem”. Był to przypadek. Znajomy oficer zaproponował mi pracę wykładowcy w szkole oficerskiej, w toruńskiej podchorążówce. Tam zatrudniano cywilnych wykładowców, bo ci podchorążacy byli zazwyczaj bez matury, którą musieli czymś zastąpić. Bardzo mi się tam podobało. Zabawne były zwłaszcza początki zajęć, kiedy słyszałem: „Obywatelu profesorze melduję pluton...". Wszyscy stali na baczność, a ci meldujący to sami frontowcy, naturalnie znacznie ode mnie starsi.

RF: Uczył Pan Profesor języka polskiego przez caty okres studiów?

S. Soldenhoff: Tylko początkowo. Potem zaczęli mi dodawać kolejne przedmioty. Po trzech miesiącach pracy wezwano mnie do komendanta szkoły. Przyszedł do mnie specjalny goniec z paskiem na brodzie i oznajmił podniesionym głosem: „Obywatelu profesorze, obywatel profesor ma się natychmiast stawić u komendanta". Pomyślałem sobie wtedy, że kończy mi się okres próbny, moją pracę uznano zapewne za nieporozumienie i chcą mnie zwolnić. Poszedłem więc, patrzę, a tam siedzi cała komisja: komendant generał Laszko (rosyjski Polak mówiący zabawna, łamaną polszczyzną) ${ }^{6}$ i jacyś nieznani mi oficerowie. Kazano mi usiąść. Komendant oznajmit, że przyszło pismo od Ministra Obrony Narodowej w mojej sprawie. Zaczął więc je czytać i okazało się, że w uznaniu moich osiągnięć w pracy nauczycielskiej dostanę nagrodę. Były to wprawdzie jakieś grosze, ale nagroda to zawsze nagroda. Oczywiście przedłużyli mi okres zatrudnienia. Dostałem nawet pełny etat. Wtedy właśnie zaczęli dodawać mi przedmioty. Wykładałem więc geografię,

6 Jewgienij Antonowicz Laszko (ur. 22 lipca 1903 w Łodzi, zm. ?) - podpułkownik Armii Czerwonej, generał brygady LWP. Był Polakiem, jednak podczas służby w Armii Czerwonej, do której wstąpił w październiku 1921 roku, deklarował narodowość rosyjską. Od sierpnia 1946 r. komendant Oficerskiej Szkoły Artylerii w Toruniu. Inicjator budowy Pomnika Artylerzysty w Toruniu. W grudniu 1946 r. awansowany na generała brygady. Jesienią 1957 r. powrócił do ZSRR. Dalsze jego losy nie są znane. 
język polski, biologię. Miałem nawet do swojej dyspozycji fantastyczny gabinet biologiczny z eksponatami.

RF: Miał Pan wówczas 20 lat. Można więc powiedzieć, że był Pan najmłodszym profesorem w historii polskiego szkolnictwa.

S. Soldenhoff: Bardzo tę pracę polubiłem, tym bardziej, że zaprzyjaźniłem się tam z wieloma oficerami, także z przedwojennymi i z AK. Co tydzień chodziliśmy na zabawy, było wesoło, ale harówa była ostra. Miałem 8 godzin lekcji dziennie, do tego musiałem pisać konspekty, sprawdzać klasówki. Potem, jak już prowadziłem cztery przedmioty, byłem ledwie żywy. Co prawda zarabiałem nieźle, dochodziły nadgodziny, ale szwankowało mi serce. Pamiętam, że pewnego dnia rano, jedząc śniadanie, upadłem $z$ przemęczenia na podłogę. Poszedłem do kardiologa, który stwierdził, że muszę zwolnić, bo serce może nie wytrzymać. Podejrzewał, że powodem takiego zmęczenia mogą być dziewczyny i związane z nimi ekscesy. Wyobraźcie sobie, że swoisty rekord, jaki pobiłem, był taki, że kiedyś podczas własnego wykładu zasnąłem. To było w listopadowy, ponury poranek, a wykład zaczynałem o ósmej rano. W czasie wykładu, właśnie we wspominanym gabinecie biologicznym, najzwyczajniej w świecie uciąłem sobie drzemkę. Pamiętam, że zauważył to podchorąży Wróbel, który nakazał moim słuchaczom zachowanie ciszy aż do przerwy. Zbudziłem się dopiero wtedy, gdy usłyszałem bardzo hałaśliwy dzwonek. Wróbel czekał na przerwę, podszedł do mnie w jej trakcie i oznajmił: „Obywatelu profesorze, widziałem różne rzeczy na froncie, widziałem nawet ludzi śpiących na stojąco. Ale żeby usnąć na własnym wykładzie?!". Zaimponowałem mu.

RF: Wiemy, że Pan Profesor skończył prawo, zostając magistrem tego kierunku. Następnie otrzymat Pan Profesor asystenturę na Uniwersytecie Mikołaja Kopernika na petnym etacie.

S. Soldenhoff: Tak, miałem wtedy same trójczyny, zresztą mam indeks do dzisiaj. Pamiętam egzamin u prof. Leona Kurowskiego ${ }^{7}$; egzamin-monstrum. Profesor Kurowski był znanym finansista, autorem trzytomowego skryptu z prawa. Wyobraźcie sobie, że trzeba było ten skrypt wkuć na pamięć „,od deski do deski”, aby zaliczyć przedmiot. Oczywiście, współcześnie cała ta wiedza jest bezużyteczna, gdyż te

7 Leon Kurowski (ur. 3 lutego 1907 r. w Smoleńsku, zm. 9 lipca 1998 r. w Warszawie) - polski prawnik specjalizujący się w prawie finansowym. W 1932 roku ukończył studia w zakresie prawa skarbowego na Uniwersytecie Stefana Batorego. 30 listopada 1945 r. został prowizorycznie mianowany na profesora organizowanego Uniwersytetu Mikołaja Kopernika w Toruniu. Objął tam stanowisko kierownika Katedry Skarbowości i Prawa Skarbowego (w 1949 r. przemianowanej na Katedrę Finansów). Na UMK pracował do roku 1953, w latach 1951-1952 pełnił funkcję rektora tej uczelni. W roku 1946 otrzymał tytuł profesora nadzwyczajnego, a w 1961 profesora zwyczajnego nauk prawnych. Od 1949 do 1977 r. pracował na Uniwersytecie Warszawskim. 
pozbawione sensu finanse PRL-owskie straciły aktualność. A profesor Kurowski zmuszał nas do takiego kucia, że jego skrypt śnił mi się po nocach. Za pierwszym razem oblałem egzamin, udało mi się dopiero za drugim podejściem. Studiowałem kiepsko, ale przy tej pracy zawodowej nie byłem po prostu w stanie uczyć się lepiej. Muszę wam jednak powiedzieć, że mieliśmy na ogół świetnych profesorów. Także, jeśli idzie o znajomość ówczesnych realiów. Pamiętam, na przykład, dziekana Michała Wyszyńskiego ${ }^{8}$, który posiadał partyzancką przeszłość i mimo, że było nas na roku około trzystu, to proszę sobie wyobrazić, że nas wszystkich znał z imienia. Pamięć nieprawdopodobna! Znał bardzo dobrze naszą sytuację i był wyrozumiały. Wiedział, że większość z nas pracuje lub dojeżdża do Torunia. Szedł więc nam na rękę, jeśli prosiliśmy go o przełożenie egzaminu czy wzięcie dziekanki. Pamiętam, jak do niego poszedłem po oblaniu egzaminu z finansów i takim troszkę uniżonym głosem powiedziałem: „Panie dziekanie jestem na ostatnim roku prawa...". Nawet nie zdążyłem skończyć, a dziekan przerwał mi i odpowiedział: „Stasiu, ja dobrze wiem, gdzie ty jesteś, daj spokój. A czemu oblałeś? Wywiało ci jakieś kartki ze skryptu Kurowskiego?" Ale w końcu przyklepał mi poprawkę i zaliczyłem te finanse. Co najważniejsze, nawet nie śniło mi się, że po tak kiepskim odbyciu studiów, mam jakiekolwiek szanse na to, by zostać asystentem. Ale miałem już wtedy „kolesiów”, a jak to w Polsce bywało, no i bywa, koleś na kolesia zazwyczaj może liczyć. Przyszli do mnie i zapytali: „Stasiu nie chciałbyś zostać asystentem? Bo wiesz, tworzymy zespół filozoficzny, a wiemy, że lubisz filozofię, tylko, że będzie ona prowadzona w ramach Katedry Podstaw Marksizmu i Leninizmu". Byłem już wtedy żonaty. Moja żona studiowała wówczas polonistykę i mimo, że ciągnęło mnie do Warszawy, to żona nie chciała się wyprowadzać z Torunia. Uległem i ostatecznie zostaliśmy. Na asystenturze pojawił się dość dziwny przedmiot dla pracowników, nazywający się "Szkolenie ideologiczne dla nauczycieli akademickich". Na początku dość subtelnie nazywano to „spotkaniami filozoficznymi", "odczytami filozoficznymi", ale potem przybrało to inny charakter - charakter regularnych szkoleń dla pracowników.

8 Michał Wyszyński (ur. 21 września 1890 r. w Wyżnianach, zm. 26 stycznia 1972 r. we Wrocławiu) - polski profesor prawa kanonicznego i teologii. Po zdaniu matury we Lwowie, studiował teologię na Uniwersytecie Jana Kazimierza i ukończył studia w 1915. Następnie studiował także prawo, które skończył w roku 1925. W międzyczasie uzyskał doktorat w Innsbrucku w 1918 roku, a w 1925 obronił pracę habilitacyjną z zakresu prawa kanonicznego na UJK. Tytuł profesora uzyskał w 1948. Od 1925-1929 r. pracował na Wydziale Teologicznym Uniwersytetu Lwowskiego. Na Uniwersytecie Mikołaja Kopernika w Toruniu pracował w latach 1946-1953, a od 1953 był pracownikiem Uniwersytetu Wrocławskiego. Na UMK pełnił funkcje dziekana Wydziału Prawno-Ekonomicznego (1945-1946), prodziekana Wydziału Prawa (1946-1953) i kierownika Katedry Prawa Rzymskiego (1948-1953). 
Przedmiot ten był na wszystkich Wydziałach, i proszę sobie pomyśleć, kończył się egzaminem komisyjnym! Wykładałem go więc dla pracowników między innymi chemii i biologii. Wyobrażacie sobie taką sytuację? Ja, wówczas młokos, dopiero po studiach, który wykłada podstawy leninizmu i marksizmu panom docentom, adiunktom, żonie rektora na chemii. Co więcej, musiałem być potem ich egzaminatorem. Czułem się idiotycznie. Od razu starałem się wejść w jakąś koleżeńską komitywę z moimi słuchaczami, co zresztą mi się udawało. Zawiązałem nawet sporo przyjaźni. Natomiast do partii zapisałem się dopiero po śmierci Stalina, choć wcześniej działałem już w ZMP jako przekonany marksista. Przechodziłem wówczas mocną ewolucję. Odszedłem od religii pod wpływem tych wojennych „,cierni”, o których już wspominałem. Oddalałem się też od tak zwanej „reakcji”. Pamiętam, że jeszcze dwa lata po wojnie byłem zagorzałym przeciwnikiem PRL-u. Ale później zacząłem już orientować się na marksizm i partię. Byłem pod wielkim wrażeniem odbudowy kraju, a zwłaszcza Warszawy. Nawet sobie nie wyobrażacie, jak to wszystko rosło w oczach. Ten rozmach, entuzjazm ludzi, autentyczne i szczere zaangażowanie się całego społeczeństwa dla jednej sprawy, dla odbudowy Polski. Pojechałem na Śląsk. Widziałem jak ten Śląsk rusza; te maszyny; zewsząd widać było tętniące życie i ta rewolucja edukacyjna. Bo nie wiem, czy wiecie, ale ciągnięto wówczas miliony ludzi do nauki i to w przeróżnych formach. Pomyślałem sobie wtedy: "dzieje się tu jednak coś pięknego!”. I ani śladu rusyfikacji, wręcz przeciwnie, zaczęto eksponować polską kulturę wszędzie tam, gdzie tylko można było; takie rozdmuchiwanie polskości. To mnie również przekonało do partii. Ale póki żył Stalin, nie było siły, bym do niej wstąpił, ponieważ kojarzyłem ją z mordercami z NKWD. A znacie może Zygmunta Ziembińskiego? ${ }^{9}$ Mówi wam coś to nazwisko?

RF: Naturalnie. Ziembiński był znakomitym logikiem. Na studiach korzystaliśmy z jego książki "Logika praktyczna".

9 Zygmunt Ziembiński (ur. 1 czerwca 1920 r. w Warszawie, zm. 19 maja 1996 r. w Poznaniu) - teoretyk prawa, logik, filozof. Podczas II wojny światowej przebywał na Kielecczyźnie, gdzie walczył w AK (pseud. Krótki), a także uczył się na tajnych kompletach. Ukończył prawo (1947) i socjologię (1949) na Uniwersytecie Poznańskim (od 1955 UAM), z którego Katedrą Teorii i Filozofii Prawa związał całą drogę naukową od 1946. Rozprawę doktorską obronił w 1950, w 1955 otrzymał stanowisko docenta, w 1962 tytuł profesora nadzwyczajnego i w 1969 profesora zwyczajnego. W 1962 został kierownikiem Zakładu Prawniczych Zastosowań Logiki, od 1981 Katedry Teorii Państwa i Prawa. Był autorem około 300 prac naukowych. Odznaczony Krzyżem Armii Krajowej i Krzyżem Komandorskim Orderu Odrodzenia Polski (1994). W 2013 roku, z inicjatywy absolwentów UAM, jednej z sal wykładowych na parterze Collegium Iuridicum Novum w Poznaniu nadano tytuł Auli im. Zygmunta Ziembińskiego. 
S. Soldenhoff: To prawda. Był wybitnym logikiem i filozofem, a oprócz tego był też prawnikiem. Bardzo interesująca postać. Pracował na Uniwersytecie Poznańskim. Zmarł kilka lat temu. A dlaczego pytam o Ziembińskiego? Otóż, AK pod koniec okupacji chciało odebrać moją ukochaną broń. Postawiono mnie wówczas przed takim kolegium, na którym słyszę: „No, Stachu, oddawaj tę swoją „,szóstkę”, bo cię spierzemy". Natomiast temu sądowi AK-owskiemu przewodniczył porucznik Krótki, którego ja wówczas dość dobrze znałem. Był bardzo bojowym człowiekiem, uczestniczył w walkach z żandarmerią. Cieszył się więc dużym szacunkiem jako dowódca i partyzant. Z racji mojej miłości do broni, pistoletu oczywiście nie oddałem. Sprawa skończyła się kompromisem. Pamiętam, że powiedziano mi wówczas: „Dobra zatrzymaj broń, ale pamiętaj, że jak będziesz się z nią wychylał, to damy ci taką szkołę, że popamiętasz". No i mamy rok 1965. Pojechałem do Nieborowa z prof. Tadeuszem Czeżowskim ${ }^{10}$. Celem podróży była ogólnopolska konferencja etyków. Byli tam wówczas: Tadeusz Kotarbiński, Maria Ossowska, Adam Podgórecki ${ }^{11}$, Ija Lazari-Pawłowska, Jan Szewczyk ${ }^{12}$,

10 Tadeusz Czeżowski (ur. 26 lipca 1889 r. w Wiedniu, zm. 28 lutego 1981 r. w Toruniu) - polski filozof, logik i etyk. W roku 1920 habilitował się na Uniwersytecie Jana Kazimierza we Lwowie, a w 1923 został mianowany profesorem nadzwyczajnym filozofii w Uniwersytecie Stefana Batorego w Wilnie. Wojnę i okupację przetrwał w Wilnie. W trakcie wojny ukrywał w swoim mieszkaniu osiem osób pochodzenia żydowskiego - uciekinierów z getta, a następnie, dzięki fałszywym dokumentom, pomógł im wydostać się z Wilna. W 1963 roku otrzymał za to wraz z żoną i córką medal „Sprawiedliwy wśród Narodów Świata”. Po wojnie Tadeusz Czeżowski został przesiedlony do Torunia. Uczestniczył w pracach organizacyjnych nowego uniwersytetu, na którym wykładał aż do przejścia na emeryturę w 1960 r. W roku 1979 Uniwersytet Mikołaja Kopernika przyznał mu tytuł doktora honoris causa.

11 Adam Podgórecki (ur. 16 grudnia 1925 r. w Krakowie, zm. 18 sierpnia 1998 r. w Ottawie) - polski socjolog prawa. Był profesorem Uniwersytetu Warszawskiego, współtwórcą Instytutu Profilaktyki Społecznej i Resocjalizacji. Kierował Zakładem Socjologii Norm i Patologii Społecznej. Uważany za kontynuatora pracy naukowej Leona Petrażyckiego i Marii Ossowskiej. Usunięty wraz z gronem współpracowników z uczelni (pod zarzutem „antypaństwowej działalności naukowej”), w 1977 wyjechał z Polski. Był przez kilkanaście lat profesorem Uniwersytetu Carleton w Ottawie. Gościnnie wykładał także na uniwersytetach w Chicago, Filadelfii, w Oxfordzie, na Stanford University i innych uczelniach. Był autorem ponad 20 książek i kilkuset publikacji naukowych. Zajmował się teorią socjologii, metodologią socjotechniki, socjologią prawa i moralności, dewiacją społeczna, wiedzą o państwie. W należącym do Uniwersytetu Warszawskiego Pałacu Zamoyskich znajduje się Sala im. prof. Adama Podgóreckiego.

12 Jan Szewczyk (ur. w roku 1930 w Lublinie, zm. w roku 1975) - polski filozof marksistowski. Od dwunastego roku życia należał do „Szarych Szeregów”. Uczestniczył w Powstaniu Warszawskim jako strzelec 227 plutonu harcerskiego AK na Żoliborzu. Wywieziony po kapitulacji Warszawy do Niemiec, pozostał po wyzwoleniu za granicą (Niemcy, Austria, Włochy, Wielka Brytania) - m.in. służąc w polskich formacjach wojskowych i pracując jako robotnik. Powróciwszy do kraju w 1953 r., 
no i był też wspominany Ziembiński, który mocno się garnął do filozofów, dlatego bardzo często zapraszaliśmy go na tego typu spotkania. Pamiętam, kiedyś po obiedzie wychodzę z budynku i widzę stojących Ossowską z Ziembińskim. Profesor Ossowska zapytała mnie wtedy: „Panie Staszku, może zechciałby pan pospacerować z nami po parku?". Poczułem się wyróżniony i oczywiście poszedłem. Widziałem, że Ossowska jakoś tak dziwnie się do mnie uśmiecha. W pewnym momencie Ziembiński, którego już wówczas znałem właśnie z takich spotkań filozofów, powiedział: „No Stasiu, o tobie to już wiem prawie wszystko. Wiem, że skończyłeś studia, że pracujesz na Wydziale Filozoficznym, ale powiedz mi, co się dzieje z mamą i z siostrami". Ja stanąłem całkowicie ogłupiały. Spojrzałem na niego i wówczas olśnienie: „Jezus Maria, przecież to porucznik Krótki, znany partyzant!". Trzeba przyznać, że Ziembiński miał świetnie dobrany pseudonim, jak na dwumetrowego drągala. Co za spotkanie! 20 lat po wojnie Ziembiński mnie rozpoznał. Musiał o tym mówić wcześniej Ossowskiej, dlatego ona się tak dziwnie do mnie uśmiechała.

RF: W latach 50-tych, zaczą Pan pracować jako asystent w Katedrze Podstaw Marksizmu i Leninizmu. Czy w tym okresie, a następnie po wstapieniu do PZPR, nie miał nigdy Pan Profesor problemów z powodu swojego pochodzenia? Nikt nie czynit żadnych aluzji?

S. Soldenhoff: To był rok 1953, rok śmierci Stalina. Pamiętam jeden moment, kiedy moje baronowskie pochodzenie przyniosło mi satysfakcję, a może raczej było przyczyną zabawnej sytuacji. Na początku muszę zaznaczyć, że z moim baronostwem nigdy się nie obnosiłem. Uważałem to po prostu za rzecz mało istotną. Wpływ na to miała też moja mama, która zawsze uczyła nas skromności. Poza tym w czasie wojny zetknąłem się z ogromną nędzą z wielkimi kontrastami społecznymi i zaczęła się wówczas budzić we mnie ostra lewicowość. Po I wojnie światowej na terenach byłego zaboru pruskiego moi krewni nie stracili majątku, ale w Kongresówce, po Powstaniu Styczniowym, zostali bez ziemi. W XIX wieku - co muszę podkreślić - Soldenhoffowie wojowali w Powstaniu Listopadowym i w Powstaniu Styczniowym. W XVIII wieku Soldenhoffowie byli na ogół dziwnymi postaciami, tacy kosmopolici, nie wiadomo czy to Polacy, Niemcy czy Rosjanie. Przewijali się po róż-

skończył liceum korespondencyjne, pracując równocześnie jako górnik i metalowiec. W 1957 r. podjął studia filozoficzne na Uniwersytecie Jagiellońskim, a po ich ukończeniu, w 1962 r., rozpoczął pracę naukowo-dydaktyczną w Katedrze Filozofii Uniwersytetu Jagiellońskiego. Doktorat z filozofii uzyskał w 1966 r., na podstawie rozprawy napisanej pod kierunkiem Romana Ingardena. Od 1969 r. aż do śmierci był pracownikiem naukowym Ośrodka Badania Stosunków Wschód-Zachód w Warszawie. Autor wielu artykułów naukowych w polskich czasopismach filozoficznych, teoretyk marksizmu jako „filozofii pracy”. 
nych armiach, niektórzy byli hochsztaplerami. Wiem o tym, ponieważ zająłem się kiedyś przeszłością mojego rodu i w tym XVIII wieku natknąłem się na przedziwnych przodków. W tym samym wieku Soldenhoffowie uzyskali szlachectwo polskie. Mam nawet kopię tego aktu. Przysłała mi go pewna doktorantka z Warszawy, która pracowała w archiwum. Akt zawierał potwierdzenie nadania tytułu baronowskiego Soldenhoffom przez Radę Królewską. A jakie tam figurują nazwiska... Sami Czartoryscy, Radziwiłłowie, Sapiehy. Od tego więc momentu Soldenhoffowie zaczęli oficjalnie funkcjonować jako baronowie polscy, mimo że wcześniej polskość mego rodu była wysoce wątpliwa. Wiem, że jednego aresztował Jan Kiliński w czasie insurekcji kościuszkowskiej za to, że dostarczał broń targowicy. Przy okazji był on jakimś szulerem, zapalonym karciarzem. Miał stale jakieś nowe majątki, między innymi knajpę warszawską o pięknej nazwie: „Ostatni grosz”. Co prawda barwna postać, ale taka trochę spod ciemnej gwiazdy ${ }^{13}$. Po Powstaniu Styczniowym Soldenhoffowie zostali bez ziemi. Moja najbliższa rodzina to już baronowie bez ziemi. Wracając do poprzedniego wątku: kiedy mnie baronostwo ucieszyło? Otóż, gdy zostałem asystentem UMK w 1953 r. nigdy nikomu nie mówiłem o swoich korzeniach. Nikomu się nie chwaliłem. Do głowy mi to nie przyszło. Zdarzyła się jednakże zabawna historia. Delegacja UMK pojechała na pogrzeb do Warszawy, na Powązki. Chowano wtedy jakiegoś profesora i ta delegacja na tamtejszym cmentarzu odkryła grób rodziny Soldenhoffów. Leży tam rzeczywiście całe grono moich krewnych: dziadek, stryj zabity przez Niemców, o którym już mówiłem. Owa delegacja wróciła do Torunia, a jeden z uczestników pogrzebu, skłonny do politycznych wzruszeń, od razu pobiegł do komitetu partyjnego i powiedział: „Wiecie, kim jest Soldenhoff? Baronem!" Przypominam, że były to czasy stalinowskie w pełnym rozkwicie, więc baronowie nie mieli najlepszych opinii. Ja oczywiście nic nie wiedziałem o tym odkryciu, o tym, że w komitecie zaszumiało z powodu zatrudnienia jakiegoś barona w Katedrze. Otrzymałem telefon: „Towarzysz Soldenhoff?". Odpowiedziałem: „Tak”, choć nie byłem jeszcze w partii. „Dzwonię z komitetu wojewódzkiego. Chcę towarzysza zapytać: czy ma towarzysz jakiś związek z grobem rodzi-

13 Antoni Aleksander Soldenhoff - generał-major wojsk koronnych, kolejno dyrektor generalny i dzierżawca huty w Miedzianej Górze 1782-1797, członek konfederacji targowickiej. Z pochodzenia był czeskim Niemcem. Ze służby austriackiej przeszedł do rosyjskiej, w 1773 roku został pułkownikiem wojsk polskich. W Warszawie służył kolejnym ambasadorom i posłom Katarzyny II, pobierając od nich żołd. W czasie sejmu grodzieńskiego w 1793 roku, stale przebywał u boku Jakoba Sieversa. Po zwycięstwie insurekcji warszawskiej aresztowany 20 kwietnia 1794, uwolniony po indagacji przeprowadzonej 13 lipca. Po upadku powstania zasiadał w przybocznej kancelarii komendanta Warszawy, Friedricha von Buxhoevedena. 
ny Soldenhoffów na warszawskich Powązkach?”. Odrzekłem: „Wiecie co, Pan Bóg pozwolił, że się cieszę znakomitym zdrowiem i żadnego związku z jakimkolwiek grobem na razie nie odczuwam". Pamiętam, że słyszał tę rozmowę mój kolega, który potem powiedział mi, że w komitecie wojewódzkim zapanowała ogromna wesołość. Ukuto wtedy zwrot: „towarzysz baron”. Od tamtej pory tak rzeczywiście zaczęto się do mnie zwracać. Wtedy właśnie poczułem satysfakcję płynącą z mego baronostwa. To były chwilami zabawne czasy, mimo że za dowcipy polityczne szło się do więzienia. Mój kolega dostał trzy lata za dowcip o Konstantym Rokossowskim. Dowcipy jednak kwitły jak stokrotki na łące i były fantastyczne. Nigdy nie zapomnę, jak wielkie poruszenie w PRL-u, od najwyższych stołków po niziny, wywołał dowcip pewnego dziennikarza partyjnej gazety z Wrocławia. Tenże delikwent, w czasie jednego z nocnych dyżurów, wymyślił kapitalną historię. Wówczas cała Polska czekała na całkowite zaćmienie słońca, a więc wydarzenie bardzo rzadkie. To był chyba 1953 rok. A ten wesołek w środku nocy zadzwonił do komitetu centralnego, powiedział, że dzwoni z obserwatorium astronomicznego we Wrocławiu i ma do przekazania bardzo ważny komunikat. Komunikat brzmiał: „Odwołujemy zaćmienie słońca, proszę poinformować o tym środki przekazu”. I wyobraźcie sobie, że ten zaspany pracownik komitetu nadał owemu komunikatowi urzędowy bieg.

RF: Jak Pan Profesor postrzegat wówczas Toruń? Bo można powiedzieć, że w porównaniu z Poznaniem czy Warszawa było to wówczas miasto prowincjonalne.

S. Soldenhoff: Nigdy nie byłem wielbicielem Warszawy. Zostało mi to do dziś. Mimo ciągłych zaproszeń do stolicy ze strony moich przyjaciół, nie mogę się jakoś zmobilizować do wizyty. Jeżdżę tam głównie na pogrzeby. Poza tym Toruń coraz bardziej mi się podobał. Pracując tutaj w czasach - co tu dużo mówić - dość ciężkich, nigdy nie miałem nieprzyjemności ani nacisków dotyczących tego, co i jak mam wykładać. Nie spotykałem się też z żadnymi pretensjami, czy z krytyką ze strony studentów. Zajęcia starałem się prowadzić swobodnie. Każdy mógł wypowiedzieć swoje zdanie. Nie ograniczałem nigdy wolności dyskusji na zajęciach. Podchodziłem liberalnie. I co ciekawe, nigdy nie miałem z tego tytułu poważniejszych problemów ze strony partii. Oczywiście, zdarzały się niekiedy ką́liwe komentarze, ale nie pamiętam, by ktokolwiek z komitetu wzywał mnie na dywanik.

RF: Jak Pan Profesor wspomina wspótprace z profesorem Adamem Schaffem?

S. Soldenhoff: Do Schaffa jeździłem na seminaria, kiedy byłem jeszcze asystentem w Toruniu. Wówczas nie byłem jeszcze związany for- 
malnie z Warszawą. Tam poznałem Krzysia Pomiana ${ }^{14}$, z którym się zaprzyjaźniłem. Krzysiu był bardzo kulturalnym i inteligentnym Żydem, podobnie zresztą jak Schaff, który pochodził z rodziny żydowskich adwokatów, w duszy był prawdziwym europejczykiem, człowiekiem tolerancyjnym, kulturalnym, znającym języki obce. To, co napisał Leszek Kołakowski o Schaffie, w ogóle mnie nie przekonuje. Kołakowski - odkąd pamiętam - zawsze traktował Schaffa trochę lekceważąco.

RF: Właśnie Panie Profesorze, Kołakowski pisał o Schaffie, że jego warsztat filozoficzny nie był wystarczająco dobry.

S. Soldenhoff: Nieprawda, Schaff był doskonale wykształcony. Poza tym, to pierwsze seminarium, na które jeździłem do Schaffa, było poświęcone Karlowi Mannheim'owi, nie marksizmowi. A Mannheim, jak zapewne wiecie, był - w przeciwieństwie do Marksa czy Engelsa - „ideologiem liberalno-burżuazyjnym". Seminarium było prowadzone niezwykle kompetentnie. W żadnym razie nie było to jakieś znęcanie się nad Mannheim'em, a dogłębne studiowanie ciekawej koncepcji. Pracę w Warszawie zaproponował mi właśnie Schaff, choć wiedziałem, że za tym pomysłem krył się Marek Fritzhand ${ }^{15}$. Pamiętam, że wówczas miałem już przechył w stronę etyki, która coraz mocniej mnie interesowała.

14 Krzysztof Pomian (ur. 25 stycznia 1934 r. w Warszawie) - polski filozof, historyk, eseista. W trakcie II wojny światowej został wywieziony z rodziną do Kazachstanu, gdzie zmarł jego ojciec. Do Polski powrócił wraz z matką w 1946. W latach 1952-1957 studiował na Wydziale Filozoficznym Uniwersytetu Warszawskiego. Na tym samym Wydziale obronił pracę doktorską (1965) i habilitacyjną (1968) oraz pracował jako adiunkt w Katedrze Historii Filozofii Narodowej. W 1966 po wygłoszeniu krytycznego wobec partii referatu został wykluczony z PZPR, do której należał od czasów studenckich. W 1968 stracił pracę na uczelni za poparcie udzielone uczestnikom wydarzeń marcowych. Do 1972 był zatrudniony w dziale rękopisów Biblioteki Narodowej, następnie wyjechał do Francji. W 1984 został profesorem we francuskim Krajowym Ośrodku Badań Naukowych. W 1998, postanowieniem Prezydenta RP, otrzymał tytuł profesora nauk humanistycznych. W 1999 r. objął stanowisko profesora na Uniwersytecie Mikołaja Kopernika w Toruniu. W 2001 został dyrektorem tworzonego w Brukseli Muzeum Europy. Jest autorem prac o filozofii współczesnej oraz związkach filozofii z polityka, m.in. zbioru esejów Filozofowie w kręgu polityki. W roku 2003 Uniwersytet Marii Curie-Skłodowskiej przyznał mu tytuł doktora honoris causa.

15 Marek Fritzhand (ur. 12 października 1913 r. w Budaczu, zm. 2 grudnia 1992 r. w Warszawie) - polski filozof marksistowski i etyk pochodzenia żydowskiego. Profesor Uniwersytetu Warszawskiego. Naukowa działalność Fritzhanda przyczyniła się do rozwoju i utrwalenia w Polsce (ale nie tylko, jako że jego prace były tłumaczone na wiele języków świata) zainteresowań etyką marksistowską. Jako jeden z pierwszych wprowadził w Polsce na szerszą skalę problematykę metaetyki (wówczas odrzucaną przez oficjalny marksizm). W latach 1972-1980 przewodniczący Komitetu Nauk Filozoficznych Polskiej Akademii Nauk. Był założycielem drugiego, po amerykańskiej „Ethics”, czasopisma naukowego, specjalnie poświęconego teoretycznym i normatywnym zagadnieniom etyki - „Etyka”. Wychowawca kilku pokoleń adeptów i profesorów etyki w Polsce. 
Tyle tylko, że wtedy w Warszawie nie było żadnej Katedry Etyki. Istniała Katedra Ogólnofilozoficzna, prowadzona przez Schaffa. Tam też zostałem zatrudniony jako asystent. Zatrzymałem jednak pół etatu w Toruniu na prośbę prof. Czeżowskiego, który chciał, bym prowadził zajęcia z etyki. Pamiętam, że wówczas w Toruniu na filozofii było zaledwie pięciu studentów, taki tu był słabiutki nabór.

RF: A czy profesor Czeżowski pracowat wówczas czynnie na Uniwersytecie Mikołaja Kopernika?

S. Soldenhoff: Tak, chodziłem do niego na seminaria. Świetnie je prowadził, ale też materiał dobierał niezwykle interesujący. Pamiętam, że niekiedy wychylałem się z moim marksizmem. Czeżowski zawsze reagował tolerancyjnie, mówiąc: „Panie Staszku, na Boga, Lenin nie był żadnym filozofem". Czeżowskiego zawsze miło wspominam. On był taki spokojny i wyrozumiały; bardzo go lubiłem. Można go określić dwoma słowami: dobry człowiek.

RF: Te seminaria, o których Pan Profesor wspomina, byty prywatne?

S. Soldenhoff: Tak, prywatne, wyproszone przez asystentów. Pamiętam, jak Czeżowski dowiedział się, że będę pracował na Uniwersytecie Warszawskim. Zrobiło mi się trochę głupio, bo przecież szlif filozoficzny zdobyłem w Toruniu. UMK finansował też moje studia. Miałem nawet płatny urlop. Czeżowski, jak to on, nie widział w tym żadnego problemu. Powiedział mi wtedy: "A to dobrze, panie Staszku, niech pan się u mnie zatrudni na pół etatu. Przecież może pan dojeżdżać". I wtedy mi się trochę poskarżył na Elzenberga. Powiedział, że po październiku z trudem wywalczył reaktywowanie filozofii w Toruniu, bo wcześniej wstrzymano tu rekrutację. Oczywiście, chciałbym wam przypomnieć, że od razu po wojnie studia filozoficzne w Toruniu odbywały się. Studiował tu między innymi Bogusław Wolniewicz, na studiach prawniczych był Zbigniew Herbert, który przyjaźnił się z Elzenbergiem. Ale potem nabór na filozofię nagle wstrzymano. Przywrócono go po październiku, w czym największa zasługa Czeżowskiego. Nabór był niewielki, ale był! Czeżowski strasznie się z tego ucieszył. Był mi też wdzięczny, że zgodziłem się dojeżdżać do Torunia i pracować tutaj na pół etatu. Okazało się, że te wykłady, które zostały mi przydzielone, były po Elzenbergu. Czeżowski powiedział mi wówczas, że Henio bardzo mocno angażował się, aby reaktywować filozofię $\mathrm{w}$ Toruniu, ale kiedy już to się udało, to nagle zrezygnował z prowadzenia zajęć, motywując to stwierdzeniem, że „ma lęk przed studentami”. Elzenberg już taki był. Miał niekiedy jakieś nerwicowe reakcje. W efekcie wycofał się, zostawiając Czeżowskiego na lodzie. No więc na zajęciach z etyki pojawiłem się ja, jako taka namiastka Elzenberga.

RF: Panie Profesorze, jakie byty relacje między Czeżowskim a Elzenbergiem? Bo z tego, co wiemy, byty to osoby psychologicznie różne. 
S. Soldenhoff: Oni się niewątpliwie bardzo lubili. Co oczywiście nie znaczy, że nie dochodziło między nimi do polemik. Czeżowski był niesłychanie uporządkowany, skrupulatny, obowiązkowy. Miał osobowość urzędniczą. To nie wzięło się znikąd. W latach 20-stych był przecież dyrektorem departamentu. Powołano go na urzędnika w Ministerstwie Wyznań Religijnych i Oświecenia Publicznego. On wręcz kochał tę administracyjno-urzędniczą robotę. Myśmy się troszkę z niego nabijali. Każdy jego asystent w Katedrze Logiki - a załogę miał niedużą - musiał wypełniać pewne obowiązki. Byli tam wówczas: Leon Gumański, Sławek Rogowski ${ }^{16}$, bardzo wybitny umysł, z wykształcenia polonista, ale też świetny filozof (nie wiem, co się z nim teraz dzieje; być może już nie żyje). Był też Wacuś Kubik ${ }^{17} \mathrm{i}$ jeszcze kilku, których już nie pamiętam. Każdy z nas otrzymywał od Czeżowskiego jakieś zadania. Moim obowiązkiem było nakręcanie ściennego zegara. Musiałem to robić bardzo skrupulatnie. I jeszcze jedno, Czeżowski uwielbiał pożyczać nam pieniądze. Nie był człowiekiem bogatym, ale miał swój sejf, czy taką skrzynkę na kluczyk, już nie pamiętam. Czeżowski interesował się naszym życiem prywatnym, w taki ojcowski sposób. Pamiętam, jak mówił do nas: „Słuchajcie moi mili, jak byście byli kiedyś w potrzebie, to zwracajcie się do mnie, jeśli idzie o pomoc finansową. Nie jestem wprawdzie milionerem, ale na ile będę mógł, to wam pomogę". A myśmy rzeczywiście czasem byli w sytuacji niewesołej. Brakowało nieraz do pierwszego, bo pensje nie były wysokie. Pożyczka u Czeżowskiego wyglądała jak rytuał. On był zachwycony, jeśli mógł pożyczyć komuś pieniądze. Wyciągał wtedy tę swoją skrzynkę pancerną. Miał zawsze przygotowane kwitki. Mówiliśmy na nie "rewersy”. I każdy, kto chciał pożyczyć jakąś sumę, musiał taki rewers podpisać. Najważniejszy był termin zwrotu, którego trzeba było sumiennie przestrzegać. Jeśli ktoś się wywiązał i oddał pieniądze $w$ terminie, to Czeżowski od razu proponował kolejną pożyczkę. I to była taka niekończąca się zabawa - cały "Czeżosiu”! Jak on mnie kiedyś skarcił, ale tak po swojemu, po ojcowsku i dobrotliwie. Pewnego razu goniec przyniósł jakieś pismo, a ja się trochę spieszyłem. Zanoszę to pismo do Czeżowskiego i mówię: „Panie Profesorze, właśnie przyszło jakieś pisemko”, a Czeżowski na to: „Panie Staszku, jak to pisemko? Przecież to jest pismo urzędowe z pieczęcią, a pisma urzędowe dzielą się na wnioski, sprawozdania itd.". Był mocno poruszony, że nazwałem pismo urzędowe pisemkiem. Cierpiał z tego powodu, ale mówię wam, był uroczym człowiekiem. Natomiast jeśli idzie o Elzenberga, to był filozofem chyba głębszym od Czeżowskiego. Weźmy, dla przykładu, pozalogiczne pisma Czeżowskiego. Znajdziemy tam kilka perełek.

16 Sławomir Rogowski, doktor w latach 1963-1970, docent w Katedrze Logiki UMK.

17 Wacław Kubik, doktor, w latach 1955-1988 adiunkt w Katedrze Logiki UMK. 
Ja najwyżej cenię ten jego szkic o sensie życia. To jest majstersztyk. Natomiast Odczyty filozoficzne są dla mnie trochę nudne. Podobają mi się jego eseje. Do nich miał talent. Natomiast Elzenberg ma w swoim dorobku kilka naprawdę świetnych studiów; takich niedużych, też - można by rzec - eseistycznych. Natomiast Czeżowskiego bardziej ceniłem jako człowieka. Choć muszę przyznać, że i z Elzenbergiem nie miałem nigdy żadnych konfliktów. Wiedział, że jestem marksista, a mimo to traktował mnie przyjaźnie.

RF: Pan Profesor chyba czuje się bardziej uczniem profesora Fritzhanda niż Schaffa?

S. Soldenhoff: Z Fritzhandem bardzo mocno się zaprzyjaźniłem. To zresztą była jego inicjatywa. Najpierw zaczęło się od oficjalnych kontaktów. Fritzhand był świetnym promotorem. Bardzo mocno się nami przejmował. Potrafił godzinami spacerować po Warszawie ze swoimi studentami i rozmawiać z nimi o ich pracach. Nauczyłem się od niego bardzo wiele, zwłaszcza tych warsztatowych, metodologicznych i analitycznych umiejętności. Schaffa wspominam bardzo ciepło, on był jednak zbyt mocno zalatany jako szef, żeby poświęcać nam tyle czasu, co Fritzhand. Schaff był bardzo kulturalny i, mimo swego zapracowania, uczynny, jeśli ktoś go o coś prosił. A poza tym nigdy nikomu nie narzucał pola badawczego. Przecież połowa załogi Schaffa to byli niemarksiści. Na jego seminariach panowała zupełna swoboda wypowiedzi. Pamiętam Sławka Jędrzejewskiego - bardzo inteligentny chłopak. On się zawsze z Schaffem spierał. Mówił nieraz do Schaffa: „Panie Profesorze, żeby krytykować tę książkę, to najpierw trzeba ją przeczytać". Wyobrażacie sobie?! Takie uwagi zgłaszał asystent swojemu promotorowi i szefowi! Byłem kiedyś ze Sławkiem na dyżurze i ktoś zapytał nas o profesora Schaffa. Sławek odezwał się: „Profesora Schaffa nie ma w Warszawie, bo pojechał do Moskwy po instrukcje". Potem była zabawa, bo kiedy Schaff już wrócil, odbywało się zebranie Katedry i na tym zebraniu Schaff, ni z gruszki, ni z pietruszki, powiedział do Sławka: „Kolego Jędrzejewski, wiem, że uwielbiacie kawior, dlatego przywiozłem wam słoik dobrego, czarnego kawioru. I jak sami widzicie, pamiętałem nie tylko o instrukcjach z Moskwy, ale też o kawiorze". Sławek zgłupiał. Okazało się, że tamten człowiek to był jakiś znajomy Schaffa, i musiał mu o wszystkim powiedzieć. Ze strony Schaffa nie było oczywiście żadnej mściwości, choć można powiedzieć, że Sławek zachował się dość bezczelnie. Schaffowi jednak to nie przeszkadzało. Miał poczucie humoru.

RF: Adam Schaff zachowywat się bardzo przyzwoicie, kiedy władza PZPR-u chciała wyraźnie ograniczyć wolność na UW.

S. Soldenhoff: To była poważna historia. Bo tak zwani burżuazyjni filozofowie $\mathrm{w}$ krajach ludowych $\mathrm{z}$ reguły lądowali $\mathrm{w}$ więzieniach lub obozach. Poznałem takich panów w Czechach, którzy z racji swoich burżuazyjnych poglądów byli osadzeni w łagrach. W Polsce żadnemu włos 
z głowy nie spadł, dzięki Schaffowi właśnie, to nie ulega żadnej wątpliwości. Jedyną represją stosowaną wobec takich filozofów było odsunięcie ich od dydaktyki, ale brali oni pensje, byli dalej profesorami. Mogli sobie organizować $\mathrm{w}$ domach prywatne seminaria, co zresztą ogromna większość z nich robiła. W Toruniu doskonałym przykładem był Elzenberg. Ja nigdy nie zapomnę, jak krótko po represjonowaniu Elzenberga, to jest odsunięciu go od dydaktyki - co, mówiąc na marginesie, specjalnie mu nie przeszkadzało - była inauguracja i przyjechał ktoś z ministerstwa. Najwyższe odznaczenie przyznano wówczas Elzenbergowi. Takie to, moi drodzy, były różne dziwactwa PRL-u.

RF: Panie Profesorze, ta otwartość $i$ ten klimat intelektualny, jaki panował wówczas w Warszawie, to - można powiedzieć - było dość niezwykłe. To rozdyskutowanie, nieograniczanie pracowników naukowych tylko do filozofii kanonicznej, marksistowskiej tłumaczyłoby między innymi fakt, że Pan Profesor w latach 60-tych, dość nieoczekiwanie, napisat doktorat z Williama Davida Rossa, a nie, na przyktad, z podstaw bytu społecznego György Lukács'a.

S. Soldenhoff: Tak, ale to nie było nic dziwnego, ponieważ na naszym Wydziale była masa tego typu doktoratów, niedoktrynalnych. To samo miało miejsce u Schaffa. Ja z tamtych czasów wyniosłem zasadę, że każdy mój doktorant czy magistrant miał wolny wybór, jeśli idzie o tematykę filozoficzna, ale jednocześnie uczulałem, że nie będę promotorem prac politycznych. Żadnego z moich podopiecznych się dziś nie wstydzę. Jeśli idzie o moją rolę jako promotora, to przypomina mi się Witek Tulibacki ${ }^{18}$, fantastyczny facet z Olsztyna. Znacie go?

RF: Oczywiście. Profesor Tulibacki pracowat na Uniwersytecie Warmińsko-Mazurskim w Olsztynie. Zmart kilka lat temu.

S. Soldenhoff: Zgadza się. Witek wybrał sobie na temat pracy doktorskiej etykę Kotarbińskiego. Pracę napisał bardzo ostra, krytyczną. W sprawie tej interweniowała nawet Ija Lazari-Pawłowska. Napisała do mnie list, w którym podkreślała, że nie wypada takich rzeczy pisać o Kotarbińskim. Witek po prostu troszkę podważał tę posągowość Kotarbińskiego. Bo ta jego etyka jest prościuteńka, sympatyczna, ale na pewno nie jest należycie pogłębiona. No i jest obrona doktorska. Tulibacki oczywiście w roli bohatera i wtedy ktoś z komisji pyta doktoranta: "Co najbardziej ujęło pana w twórczości profesora Kotarbińskiego?”. A Witek na to: „Nic". Natomiast wracając do Torunia, na radach Wydziału Hu-

18 Witold Tulibacki (ur. 20 grudnia 1945, zm. 13 stycznia 2006) - polski filozof, w latach 2000-2006 rektor Olsztyńskiej Szkoły Wyższej im. Józefa Rusieckiego. Od 1969 roku związany z olsztyńskimi uczelniami. Po utworzeniu Uniwersytetu Warmińsko-Mazurskiego objął stanowisko profesora w Instytucie Filozofii na Wydziale Humanistycznym tej uczelni. Po tragicznej śmierci Józefa Rusieckiego, 7 grudnia 2000 roku został wybrany rektorem Olsztyńskiej Szkoły Wyższej. Funkcję tę pełnił do śmierci. Tytuł profesora uzyskał w 2001 roku. Specjalizował się w aksjologii i etyce. Wydał blisko trzysta publikacji. 
manistycznego zaczęto $\mathrm{w}$ pewnym czasie coraz częściej zahaczać o tematy prac moich doktorantów. Nawet kiedy występowałem z jakimiś wnioskami personalnymi, to zawsze znalazło się kilku mądrali, którzy mieli coś do powiedzenia; ciągle się im coś nie podobało. Oczywiście o filozofii nie mieli zbyt dużego pojęcia, ale nie przeszkadzało im to, by pytać: „Czy aby ten temat się nadaje?". Pewnego dnia się zirytowałem. Miałem wówczas referować wniosek o otwarcie przewodu doktorskiego dotyczącego filozofii Franza Brentano. Referuję więc ów wniosek, a tu jakiś facet mówi mi, że wprawdzie nie jest specjalistą w tej dziedzinie, ale Brentano to chyba nie jest jakaś wielka postać w filozofii i nie nadaje się na temat pracy doktorskiej. Ja odrzekłem wtedy do moich sąsiadów: "Zaraz zrobię go na szaro". Wystąpiłem więc z mową obronną wniosku i powiedziałem tak: „Brentano to jest jednak postać wybitna, jeśli idzie o współczesną filozofię, ale to nic. Poza zainteresowaniami spekulatywnymi, czysto filozoficznymi, miał on też pomysły i osiągnięcia praktyczne; był wynalazcą maszynki do mielenia mięsa". Moi sąsiedzi zaczęli konać ze śmiechu, a tamci mieli dość niewyraźne miny. Osobiście nigdy nawet do głowy mi nie przyszło, by się wtrącać w cudze doktoraty. Powiedzcie sami, jak ja mogłem merytorycznie oceniać zasadność wniosku o otwarcie przewodów doktorskich jakiegoś polonisty czy historyka. Ja się po prostu na tym nie znam i co mam się tu mądrzyć. Istnieje jakiś podział ról i to uszanujmy.

RF: Panie Profesorze, jak Pan Profesor wspomina prace nad swoim doktoratem z filozofii etycznej Rossa? Ciężko było wówczas o materiały?

S. Soldenhoff: Miałem trudności z wyborem tematu. Najpierw zacząłem studiować Roberta Owena, potem przerzuciłem się na Johna Deweya. Na tych dwóch poświęciłem trzy lata. Potem przyszedł pomysł na Rossa. Podsunął mi go chyba Fritzhand lub Ossowska, która była mocno rozmiłowana w filozofii analitycznej, co zresztą doskonale widać w jej twórczości. Czeżowski też pochwalał mój wybór. Uważał, że Ross to wybitny i ciekawy myśliciel. Muszę wam powiedzieć, że Ross rzeczywiście mnie wciągnął. Lubię go za jego umiarkowanie. Każdy sąd wypowiadał, ważąc go. Nie popadał w radykalizm. Poza tym widać w jego pismach filozoficzną precyzję, co jest zresztą znamienne dla analityków. Potrafią oni nie tylko rozbierać na kawałki różne koncepcje, najczęściej z negatywnymi wnioskami, ale dają przy tym własne, ciekawe propozycje. W tej sprawie nie zgadzałem się z Schaffem. On uważał, że analitycy wprowadzają do filozofii tylko destrukcję, że wyszukują same słabości doktryn, kierunków, nurtów. Analitycy - twierdził Schaff - rozkładają zagadnienia filozoficzne na czynniki pierwsze, ale potem nie da się już nic z tym zrobić, nie można później złożyć tych pierwiastków w sensowną całość. Schaff cenił w filozofii twórczość, pomyślunek, świeżość myślenia, a tego $u$ analityków nie mógł dostrzec. $W$ tej kwestii nie mogłem się z nim zgodzić. Weźmy, dla przykładu Georga Edwarda Moore’a. On 
przecież miał pomysły i to nie byle jakie. Jego rozłożenie na łopatki utylitaryzmu było tak druzgocące, że potem utylitaryzm już się nie podniósł, ale oprócz tego sam miał przecież oryginalne pomysły. Choćby jego koncepcja intuicjonizmu jest bardzo aktualna i ciekawa.

RF: Jak Pan wspomina profesora Bogusława Wolniewicza, który często Henryka Elzenberga nazywa swoim mistrzem?

S. Soldenhoff: Znam Wolniewicza od lat 50-tych. On studiował $\mathrm{w}$ Toruniu filozofię $\mathrm{w}$ tym samym czasie, kiedy przebywał tu Zbigniew Herbert. Wolniewicz jest bardzo lojalnym uczniem Elzenberga i rzeczywiście mówi o tym dość często. Miał też na pewno bliskie kontakty z Elzenbergiem. Wolniewicz był zawsze trochę dziwakiem, a pamiętam go jeszcze z czasów licealnych. Bardzo go cenię, przede wszystkim za odwagę cywilną i bezkompromisowość. Niezwykle odważnym człowiekiem był również Tadeusz Płużański ${ }^{19}$, z którym się przyjaźniłem. Jego śmierć kilka lat temu mocno mnie przygnębiła. Płużański miał straszne przejścia w okresie PRL-u, ponieważ był uwikłany w sprawę Rotmistrza Pileckiego i na tej samej rozprawie, na której skazano Pileckiego, Płużański i jego żona otrzymali wyroki śmierci. Spotkałem go kiedyś w Warszawie. Był jakiś taki nieswój. Powiedział wtedy do mnie: „Staszek cały się trzęsę. Wyobraź sobie, że spotkałem dziś tę straszną babę, którą pamiętam z kryminału, kiedy siedziałem na Rakowieckiej z wyrokiem śmierci. Spotkałem ją dziś z pieskiem na smyczy. Okazało się, że jest moją sąsiadką. Wówczas była mecenasem i pamiętam, jak czekałem na wykonanie wyroku. Ona zapytała mnie, jakie jest moje ostatnie życzenie. Ja, naturalnie, chciałem się spotkać z żona, na co ten babsztyl odparł, po cóż z żoną, przecież zobaczę się z nią niedługo, w niebie".

RF: Panie Profesorze, podczas swoich studiów, ale i później, zetknąt się Pan Profesor z legendami polskiej myśli filozoficznej, pomijajac chociażby takie nazwiska - o których już mówiliśmy - jak Czeżowski, Elzenberg, Schaff czy Fritzhand, miat Pan Profesor okazje poznać takie osobowości, jak: Ossowska, Kotarbiński, Kołakowski, Baczko, same znakomitości.

19 Tadeusz Płużański (ur. 15 sierpnia 1920 r. w Miechowie, zm. 16 sierpnia 2002 r. w Warszawie) - uczestnik kampanii wrześniowej, więzień stalinowski, historyk filozofii, pisarz, pedagog. W latach 1940-1945 więzień hitlerowskiego obozu w Stuthoff. Za działalność konspiracyjną w tak zwanej "grupie Pileckiego" został aresztowany w 1947 roku i w następnym roku skazany w procesie pokazowym na karę śmierci, którą następnie zmieniono na dożywotnie więzienie. Wolność odzyskał w 1956 roku. W roku 1957 rozpoczął studia na Wydziale Filozofii Uniwersytetu Warszawskiego. Stopień magistra uzyskał w 1961 roku, wkrótce potem zrobił doktorat, a pięć lat później habilitował się. Tytuł profesora otrzymał w roku 1979. Pracował w Instytucie Filozofii i Socjologii PAN. W latach 80-tych wykładał gościnnie w Instytucie Religioznawstwa UJ, a od 1995 r. był kierownikiem Katedry Filozofii w Wyższej Szkole Handlu i Prawa w Warszawie. 10 listopada 1994 r. został odznaczony Krzyżem Oficerskim Orderu Odrodzenia Polski za wybitne zasługi na rzecz niepodległości i suwerenności Polski. 
S. Soldenhoff: Było bardzo ciekawie. Były to czasy ogromnej intelektualnej aktywności. Wszystkie nazwiska, które wymieniliście, wspominam z sympatią i szacunkiem. Oczywiście, zawsze miałem świadomość tego, że oni są ode mnie dużo wyżej, w sensie osiągnięć i poziomu, w sensie jakiejś autentycznej rangi. Ale uważałem ich za swoich sąsiadów, bo myśmy się prawie codziennie widywali, czy to na korytarzu, czy na schodach. Kołakowski miał pokój obok, Ossowska z drugiej strony. Kotarbińskiego widywałem rzadziej, ponieważ miał on wówczas wiele obowiązków. W latach 1957-1962 był przecież prezesem PAN-u. Kotarbiński był przyjacielem Władysława Gomułki. Pamiętam jedno z wystąpień Gomułki, w którym podkreślał on zasługi Kotarbińskiego dla polskiej myśli filozoficznej. Traktował go jak intelektualny autorytet. Trzeba przyznać, że jak na Gomułkę było to wystąpienie dość wyjątkowe, coś niesamowitego, same superlatywy pod adresem Kotarbińskiego. Ale pamiętam też wypowiedzi Kotarbińskiego o Gomułce. Określał go jako skromnego, przyzwoitego człowieka i - co często podkreślał - o czystych intencjach. Natomiast Kołakowski był sympatycznym sąsiadem. Każdy z nas wiedział, że jest on już ponad nami, jeśli idzie o osiągnięcia i pozycję naukową. Ale nigdy się nie wywyższał. Zawsze nastawiony do nas w relacjach koleżeńskich. Z naszej Katedry najmocniej się z nim trzymał Henryk Jankowski ${ }^{20}$. Kiedy czytałem wspomnienia Kołakowskiego, to najbardziej zdziwił mnie fakt, że nigdzie nie wymienił on Henia, a przecież $\mathrm{w}$ pewnym okresie czasu byli ze sobą $\mathrm{w}$ naprawdę bliskich relacjach. Co do Baczki ${ }^{21}$, to był świetny w improwizowanych wystąpieniach. Owszem, podoba mi się jego twórczość jako historyka

20 Henryk Jankowski (ur. 31 lipca 1929 r. w Nieświeżu, zm. 21 listopada 2004 r.) polski filozof i etyk. Ukończył dwa Wydziały Uniwersytetu Warszawskiego - prawo (1953) i filozofię (1955). W okresie okupacji należał do Szarych Szeregów, po wojnie do organizacji młodzieżowych. Od roku 1953 był wieloletnim pracownikiem UW, m.in. dyrektorem Instytutu Filozofii. W 1962 r. obronił pracę doktorską a w 1967 habilitował się. Od 1973 był profesorem nadzwyczajnym, od 1986 profesorem zwyczajnym. W roku 1981 był krótko prodziekanem Wydziału Filozofii i Socjologii UW. W latach 1987-1993 dziekan Wydziału Filozofii i Socjologii UW. W latach 1968-1992 był redaktorem naczelnym czasopisma „Etyka”.

21 Bronisław Baczko (ur. 13 czerwca 1924 r. w Warszawie) - polski filozof, historyk myśli społecznej, współzałożyciel Warszawskiej Szkoły Historyków Idei, tłumacz. Zaraz po II wojnie światowej, obok Leszka Kołakowskiego, Adama Schaffa i Tadeusza Krońskiego, główny ideolog stalinizmu w filozofii marksistowskiej. Zaangażowany przez PZPR do walki z niemarksistowskimi kierunkami filozoficznymi występującymi w Polsce i uczyniony jednym z filarów obozu marksistowskiego w dziedzinie ideologii, stopniowo przechodził na pozycje rewizjonistyczne. Wychowawca wielu pokoleń polskich filozofów i socjologów. W 1968, w trakcie wydarzeń marcowych, został wyrzucony z Instytutu Filozofii Uniwersytetu Warszawskiego i zmuszony do emigracji. Od 1974 związany jest z Uniwersytetem Genewskim (obecnie profesor honorowy tej uczelni). Zajmował się przede wszystkim historią rewolucji francuskiej, utopiami i wyobrażeniami zbiorowymi. 
filozofii, ale najbardziej go lubiłem „na żywo". Pamiętam go z różnych wystąpień i zebrań. Wybitny umysł. Z ciętym, złośliwym, ale równocześnie finezyjnym dowcipem.

RF: Pan Profesor wspominat, że kiedy Kołakowski wyróst na pewnego opozycjoniste w 1966 roku, to bardzo często otaczata go grupka wielbicieli towarzyszacych mu na każdym kroku. Ale, co ciekawe, Pan Profesor mówił nam też kiedyś, że to samo byto z Elzenbergiem. On też miał grupkę swoich klakierów.

S. Soldenhoff: Tak, to się zdarzało. Za Elzenbergiem zazwyczaj ciągnęła grupka starszych pań, wpatrzonych w niego, jak w obrazek. Niekiedy nosiły mu nawet bagaże. Konrad Górski ${ }^{22}$ również miał takie grono dyżurnych adoratorek.

RF: W 1969 roku zostaje Pan zatrudniony na stanowisku docenta.

S. Soldenhoff: Dokładnie. Po słynnym marcu 68' wróciłem z Warszawy do Torunia, a to z dwóch powodów. Moja małżonka nie chciała po prostu mieszkać $\mathrm{w}$ Warszawie, mimo że miałem dwa razy przyklepane tam mieszkanie. Zakochała się w konserwatorstwie i chciała zostać w Toruniu, a ja w żadnym razie nie miałem zamiaru do niczego jej zmuszać. Ale po drugie, wówczas wyskoczyła - zupełnie dla mnie nieoczekiwanie - propozycja, bym został kierownikiem katedry po profesorze Tadeuszu Szczurkiewiczu ${ }^{23}$, który przechodził właśnie na emeryturę.

22 Konrad Górski (ur. 22 kwietnia 1895 r. w Wąrach, zm. 7 kwietnia 1990 r. w Toruniu) - polski historyk i teoretyk literatury, specjalizujący się w historii literatury polskiej. W 1918 roku podjął studia w zakresie filologii polskiej na Uniwersytecie Warszawskim. W 1921 roku otrzymał stopień doktora nauk filologicznych. W latach 1922-1923 studiował bohemistykę na Uniwersytecie Karola w Pradze, równocześnie prowadząc tam lektorat z języka polskiego. W 1929 roku uzyskał habilitację i objął stanowisko docenta na Uniwersytecie Warszawskim. W 1934 roku otrzymał stanowisko profesora nadzwyczajnego historii literatury polskiej na Uniwersytecie Stefana Batorego w Wilnie. 1 października 1945 r. zatrudnił się na organizowanym Uniwersytecie Mikołaja Kopernika w Toruniu, gdzie na podstawie prowizorycznej nominacji rektora, wydanej 8 października, objął stanowisko profesora zwyczajnego w Katedrze Historii Literatury Polskiej oraz funkcję dziekana Wydziału Humanistycznego. Dziekanem był do 1947 roku, potem przez rok prodziekanem oraz kierownikiem Zakładu Literatury Polskiej XIX wieku. W 1950 roku został odsunięty, z powodów politycznych, od zajęć dydaktycznych i do 1956 roku pracował w Instytucie Badań Literackich PAN. Powrócił na UMK w 1956 roku i pracował na tej uczelni do przejścia na emeryturę w 1965 roku.

23 Tadeusz Szczurkiewicz (ur. 20 listopada 1895 r. w Pilźnie, zm. 6 grudnia 1984 r. w Poznaniu) - polski socjolog, uczeń Floriana Znanieckiego. Studiował filozofię i filologię polską na Uniwersytecie Jagiellońskim (1919-1921), potem filozofię kultury i socjologię na Uniwersytecie Poznańskim. W 1931 roku uzyskał na Uniwersytecie Poznańskim stopień doktora. Habilitację uzyskał w 1939 roku. Na Uniwersytecie Poznańskim pracował od 1919 roku, początkowo jako zastępca asystenta, w latach 1931-1939 prowadził wykłady z socjologii. W czasie II wojny światowej pracował jako urzędnik w Zakładzie Ubezpieczeń Społecznych w Warszawie. Zaangażował się w tajne nauczanie na Uniwersytecie Ziem Zachodnich, Uniwersytecie Warszawskim i w Wolnej Wszechnicy. 1 września 1945 r. został prowizorycznie powołany przez 


\section{stać.}

RF: Co do prof. Szczurkiewicza, styszeliśmy, że to była bardzo barwna po-

S. Soldenhoff: Oj, bardzo barwna. Szczurkiewicz wprawdzie nie zostawił po sobie dużego dorobku piśmienniczego, choć to, co napisał, jest znakomite, ale był twórczym i błyskotliwym erudytą. Szczurkiewicz nienawidził oficjalnych spotkań, celebrowania. Kiedy słyszał, że gdzieś odbywa się jakieś uroczyste zebranie, to szedł, żeby zrobić tam zamieszanie. Szczurkiewicz był na przykład krytyczny wobec Twardowskiego, że na wyrost zrobiono z niego wybitną postać w polskiej filozofii. „Co tam Twardowski?!” - mówił często Szczurkiewicz. Pamiętam, że spotkanie dotyczyło jakiejś rocznicy poświęconej Twardowskiemu. Szczurkiewicz przyszedł prosto z hotelu „Polonia”, gdzie troszkę podniecił się alkoholem. Siedział cicho, słuchał i patrzył, a miał takie fajne spojrzenie, krytyczno-ironiczne, robiąc przy tym ciekawe miny. W końcu zabrał głos w dyskusji, mówiąc: „No, wiecie Państwo, nieboszczyka może i nie wypada krytykować, ale jeśli słyszę same nabożeństwa i modlitwy pod adresem Twardowskiego, to nie mogę nie zareagować. Co to za szkoła? Jedno wielkie nieporozumienie!" Ja bym oczywiście się z nim nie zgodził, bo to było niesprawiedliwe. Ale gdybyście zobaczyli formę, w jakiej on to zrobił, to zmącenie atmosfery, miny tych adoratorów Twardowskiego, to było coś pięknego. Szczurkiewicz po prostu nie lubił celebry i egzaltacji. Podobał mu się Max Scheler. Profesor opowiadał mi kiedyś o ciekawostce z życia Schelera, kiedy ten już przeszedł na katolicyzm - a jego poglądy, jak wiecie, były poddane dość mocnej ewolucji - i miał jakiś odczyt w zakonie. Odczyt zakłócił pilny telefon. Scheler wyszedł z sali, podszedł do słuchawki i co się okazało: dzwoniła właścicielka domu publicznego, przypominając Schelerowi o zaległej należności. Cały wykład w zakonie przysłowiowi diabli wzięli. Taki był właśnie "Szczur” - jak na niego mówiliśmy! Kochał takie kąski i starannie je wyszukiwał. Trzeba jednak przyznać, że niekiedy ta „ułańska fantazja" była trochę alkoholowa, choć nigdy się nie upijał. Przyjeżdżał do Torunia i stołował się w „Polonii”. Często siedział w knajpie. Tam też spotykał się z przyjaciółmi, gdyż uwielbiał towarzystwo. Ja sam zresztą bardzo lubiłem z nim tam chodzić, bo miał niezwykły dar opowiadania. Kiedyś na zebraniu partyjnym ktoś się poskarżył, że jakaś działaczka z Ligi Kobiet z czegoś się nie wywiązała. Szczurkiewiczowi od razu błysnęło oko, ożywił się i powiedział: „Co do Ligi Kobiet, to takie

rektora Uniwersytetu Mikołaja Kopernika na stanowisko profesora nadzwyczajnego. Tytuł profesora otrzymał w 1963 roku. W latach 1945-1950 był kierownikiem zorganizowanej przez siebie Katedry Socjologii na Wydziale Prawno-Ekonomicznym UMK. Od roku 1957 do przejścia na emeryturę w roku 1966 kierował Katedrą Historii Filozofii i Myśli Społecznej. Jego głównym obszarem badawczym był zakres teorii i historii socjologii w powiązaniu z historią filozofii i myśli społecznej. 
dziwne historie mi się kojarza, mianowicie, kiedy byłem przed wojną u Znanieckiego (a Szczurkiewicz był ulubieńcem Znanieckiego), to jako socjolog badałem prostytucję w Poznaniu. Prowadziłem badania terenowe. Doszło też do bliskich kontaktów z paniami. Panie były bardzo sympatyczne. Nazywały mnie nawet „doktorkiem”. Wracając do zniszczonego Poznania po wojnie, zacząłem tych pań szukać, odwiedzałem uliczki, na których wcześniej przebywały - ani śladu. Pytałem o nie ludzi. Mówili, że chyba Niemcy je pomordowali. Zrobiło mi się ich żal. W mym sercu zapanowała nostalgia. Ale to wszystko okazało się, na szczęście, nieprawdą. Pamiętam, że to był Dzień Kobiet i właśnie przez pewną szacowną organizację kobiecą zostałem poproszony o wygłoszenie jakiegoś odczytu. Wchodzę, patrzę, a całe prezydium zgromadzone na sali to moje znajome $\mathrm{z}$ dawnych lat".

RF: Panie Profesorze, więc w 1969 r. wraca Pan Profesor do Torunia i obejmuje Katedre po prof. Szczurkiewiczu.

S. Soldenhoff: Tak, było to dla mnie kolejne nowe doświadczenie, ponieważ kiedy tu przyszedłem, znałem tylko dwie osoby, z którymi byłem na "ty". Resztę stanowiły same nowe twarze. Osoby, które widziałem wówczas po raz pierwszy, to między innymi bardzo dobrze dziś znani wam prof. Włodzimierz Tyburski i prof. Ryszard Wiśniewski. Byli świeżo po studiach. Powiem wam, że na początku byłem trochę zmieszany funkcją kierownika Katedry, która rozrastała się i już wtedy była dość duża. Zupełnie nie wiedziałem, jak ich ugryźć. Widziałem, że oni czekają bo wiedzieli, że jakiś nowy przyszedł, a ja wyczuwałem z ich strony takie oczekiwanie i zaciekawienie, co ten kierownik wymyśli, jakie będą jego pierwsze decyzje. Jako kierownik Katedry miałem swój - wprawdzie mały, ale zawsze - pokoik i kiedy odbywałem dyżury, to przychodziłem na nie z organkami. To był mój taki ruch szachowy. Na dyżurach grałem na organkach, myślałem sobie wtedy: „Oto moje pierwsze posunięcie, teraz spróbujcie je rozgryźć". Reakcja była taka: pierwszy, pamiętam, przyszedł Staszek Katafias ${ }^{24}$. Zapukał, zajrzał i szybko się wycofał, kiedy zauważył, że ja sobie gram na organkach. Z czasem pojawiali się kolejni. Muszę wam powiedzieć, że udało mi się kompletnie zbić ich z tropu.

RF: Jak Pan Profesor wspomina ten okres, bo wiemy, że od razu po powrocie do Torunia rzucit się Pan Profesor w wir organizacyjny. Wówczas powstato stynne już seminarium z etyki.

24 Stanisław Katafias (ur. 1939 r. - zm. 2008 r. w Bydgoszczy) - etyk, doktor nauk humanistycznych, wykładowca w Studium Medycyny Społecznej bydgoskiej Akademii Medycznej (obecnie Collegium Medicum UMK). Jego zainteresowania badawcze koncentrowały się wokół etyki medycznej, bioetyki i tanatologii. 
S. Soldenhoff: Tak, dopóki byłem Kierownikiem Zakładu Etyki, byłem bardzo zadowolony, ponieważ, udało mi się skupić wielu zainteresowanych, taki duży zespół autentycznie zaangażowanych ludzi. Zauważyłem też na wykładach, że ilekroć poruszam sprawy etyczne, na sali od razu panuje zainteresowanie, że studenci przerywają mi i włączają się w dyskusję, co bardzo mi się podobało. Okazało się, że - zwłaszcza etyką - interesują się dobrzy studenci i wtedy właśnie wpadłem na pomysł, żeby poza zebraniami naukowymi Katedry, uruchomić seminarium dla studentów z całego uniwersytetu. Poprosiłem kolegów, by poinformowali o tym słuchaczy. Zaczęło się od niedużej grupki z różnych Wydziałów. Byli matematycy, fizycy, biolodzy, historycy, dosyć szybko zjawili się Andrzej Zybertowicz, Leszek Witkowski i to się zaczęło świetnie rozwijać. Udało nam się przyciągnąć najlepszą młodzież z całego uniwersytetu, autentycznych prymusów i doborowe towarzystwo. Dyskusje były świetne. $Z$ czasem na zajęcia zaczęli przychodzić ludzie z zewnątrz, nierzadko $\mathrm{z}$ odpowiednich służb, bo te seminaria niepokoiły bezpiekę. Seminarium zaczęło się kruszyć, właśnie poprzez takie działania dywersyjne, poprzez podstawionych uczestników, których ja zresztą od razu rozpoznawałem. Wiedziałem, że nie przychodzą z wewnętrznej potrzeby, a są przysyłani, aby rozrabiać. W końcu dowiedziałem się, że niektórych moich studentów zaczęto wzywać na przesłuchania i tak sobie pomyślałem, że jeżeli ta młodzież ma cierpieć, to może lepiej to wygasić, zawiesić działanie seminarium, po prostu się o nich bałem. Bo to była naprawdę fajna młodzież. Raz przyjechał Władysław Tatarkiewicz i jak tylko dowiedział się o tym seminarium, o studentach, którzy przychodzą z własnej woli i są żywo zainteresowani zagadnieniami filozofii, to od razu chciał się z nimi spotkać. A tam były też świetne dziewczyny. Potem wymyśliłem naukowo-wypoczynkowy obóz w Tleniu. Udało się załatwić na to pieniądze. Mieszkałem wtedy w Grzybku, sześć kilometrów od Tlenia i dopływałem tam łódką. Pamiętam, że dziewczyny na mnie zawsze czekały z poziomkami, malinami, z koglem-moglem. Strasznie mnie hołubiły. Nigdy tego nie zapomnę. Muszę jednak przyznać, że seminaria naukowe Katedry z biegiem lat utraciły wigor i to z mojej winy. Jak szefowałem i przymuszałem trochę do udziału na tych zebraniach, do wygłaszania referatów, to w końcu z przerażeniem odkryłem, że my w dużej mierze powtarzamy tematy. Poczułem się wówczas głupio, bo to znaczyło, że straciłem kontrolę jako prowadzący. Wtedy zdarzyła się jeszcze taka sytuacja: z powodów politycznych wstrzymano, nie po raz pierwszy zreszta, nabór na studia filozoficzne. Będąc kierownikiem Katedry, musiałem rozdzielać masę zajęć, bo zajęcia prowadziliśmy na całym uniwersytecie. Wyraźnie brakowało nam magistrów. Zacząłem więc rozglądać się za nowymi pracownikami i niejako z konieczności musiałem zatrudniać niefilozofów. Część $\mathrm{z}$ nich znałem $\mathrm{z}$ tych konwersatoriów, jako takich filozofów z zamiło- 
wania. I wtedy właśnie trafił tu Leszek Witkowski po matematyce, jako najlepszy student UMK. Potem przyszedł Skałecki, jeden z najlepszych studentów na biologii i jeszcze kilku innych. Musieli więc - że się tak wyrażę - doganiać filozofię. Doktoraty robili już z tej dziedziny. To była sytuacja przymusowa, przecież Włodzimierz Tyburski jest historykiem, Ryszard Wiśniewski kończył prawo, ale w filozofii od razu się odnaleźli i świetnie sobie poradzili. Po filozofii byli wówczas Mirek i Jola Żelaźni, Andrzej Szahaj, którego - jako dobrego studenta - wyszukał mi, niedawno zmarły, Leszek Nowak. Polecał mi go też prof. Jerzy Kmita, z którym zawsze byłem w przyjaźni. Poza tym, do Torunia udawało mi się zapraszać nietuzinkowych gości. Byli tu, między innymi: Leszek Kołakowski, Jan Legowicz, Adam Sikora, Krzysztof Pomian, Jurek Kmita, Zdzisław Cackowski.

RF: Poza tymi problemami na seminarium etycznym, gdzie podsuwano "studentów", nie było żadnych innych problemów natury polityczno-ideologicznej ze Stużba Bezpieczeństwa?

S. Soldenhoff: Muszę powiedzieć, że były, ale na ogół to się dobrze kończyło. Witkowski był przecież internowany, ale tylko tydzień. Andrzeja Zybertowicza przymknęła bezpieka bydgoska, bo Andrzej, jak to Andrzej, on się zawsze mocno angażował. Pamiętam, że po miesiącu udało nam się go wyciągnąć z kryminału. Podpisałem jakieś papierki popierające wniosek o zwolnienie. Lekarze mu wymyślili raka skóry. Oczywiście, to wszystko była lipa, ale bezpieka się wystraszyła, że umrze, że zrobi się szum, że zadręczyli pracownika naukowego. Następnie, najzwyczajniej w świecie Zybertowicz wrócił do pracy. Mimo tych problemów ze Służbą Bezpieczeństwa nikt w Instytucie pracy nie stracił. To mogą wszyscy potwierdzić. A pracowało tu wówczas wielu, którzy byli bezpartyjni, więc powody do zwolnień można było znaleźć od razu. Szczególnie w stanie wojennym.

RF: Jak Pan wspomina 1989 rok i okres transformacji ustrojowej? To byt przecież czas, kiedy Instytut Filozofii miał ustabilizowana pozycję. O ile marksizm nigdy nie byt jakoś mocno obecny w polskiej myśli filozoficznej, to po 1989 roku zniknat zupetnie.

S. Soldenhoff: To był okres rozsypania się socjalizmu. Główne przyczyny tego upadku to jego wewnętrzne sprzeczności oraz kryzys gospodarczy, zwłaszcza w Związku Radzieckim, ale nie tylko tam. Socjalizm rozpadł się na własne życzenie. Oczywiście swój kamyczek dołożyli do tego Jan Paweł II, Lech Wałęsa i w ogóle "Solidarność" jako ruch społeczny. Ale główna przyczyna upadku socjalizmu tkwiła w nieudanym eksperymencie instytucjonalnym. Ja sobie to wówczas wszystko uświadamiałem. Wiedziałem, że statek tonie. Okazało się, że wszystkie próby reformowania skazane były na niepowodzenie. Natomiast po upadku socjalizmu, złościło mnie i nadal złości to głupie, bezmyślne krytykowanie tamtych czasów, przy którym zupełnie pomija się rzeczy poważne, 
rzeczywiście zasługujące na krytykę, opowiadając przy tym jakieś niestworzone głupoty. Dla przykładu, jak słyszę, że sklepach w PRL-u był tylko ocet i musztarda, to chce mi się śmiać. To nieprawda! Oczywiście mogło się to zdarzyć w jakichś zapyziałych sklepikach. Zaopatrzenie w PRL-u to też przedziwna historia, całkowity irracjonalizm. Nigdy nie wiadomo było, dlaczego jakiegoś towaru zabrakło, albo dlaczego drugiego jest za dużo. No pomyślcie sobie, jak cały naród - ponad trzydziestomilionowy - mógłby wyżyć przez tyle lat samym tylko octem lub musztardą? Głupota! Jak nie było masła, to była margaryna. Szczyt tej irracjonalności zaopatrzeniowej nastąpił przed stanem wojennym. Z rynku kompletnie zniknęły papierosy, co dla palaczy było strasznie bolesne. Można było je dostać tylko w Peweksie. Potem popuścili trochę i papierosy pojawiały się na wagę, wyobrażacie sobie? Tamtejsze zaopatrzenie z dzisiejszym jest nieporównywalne, to na pewno. Ale dziś nie ma lodów bez cukru.

RF: Czy demokracja i kapitalizm spetnity Pana oczekiwania?

S. Soldenhoff: Na pewno nie. Cała moja lewicowość lub, jeśli ktoś woli komuchowatość, polega na tym, że nie cierpię kapitalizmu. Pod tym względem się nie zmieniłem i nie zmieniam. Mnie w lewicowość wpędziły obrazy polsko-żydowskiej biedy i rozpaczy, które widziałem na początku wojny i okupacji. Strasznie to przeżywałem. I jak dziś widzę, że się traktuje ludzi po łajdacku, to wszystko się we mnie gotuje. Kiedyś w telewizji oglądałem reportaż o jakiejś biednej kobiecinie, która była poniżana przez przedsiębiorcę, chama, co tu dużo mówić. Przyszła do niego po pensję, która jej się należała, a której on nie chciał jej wypłacić. Powiedział natomiast: „Uklęknij, to dostaniesz”. Pytam się teraz: gdzie jest KOR, który bronił kiedyś robotników? I robił to słusznie i skutecznie. A po transformacji nagle wszystko ucichło, przestało się już widzieć problemy ludzi pracy. Denerwuje mnie ta oparta na nieprawdzie krytyka PRL-u. Uważam, że ten system nie zasługuje na obronę, bo się przewrócił wskutek swoich słabości. Dlaczego się nie krytykuje tej strasznej rzeczy, jaką było szaleństwo inwestycyjne, któremu nie towarzyszył żaden trzeźwy rachunek ekonomiczny, tej „radosnej twórczości" i marnotrawstwa, które doprowadziły do katastrofy? Dzisiaj nie jest lepiej. Bardzo często panuje terror w przedsiębiorstwach. Ludzie boją się pisnąć słowo, żeby nie wylecieć z pracy. To jest ograniczanie wolności, więc, na litość boska, bądźmy sprawiedliwi w ocenie jednego systemu, jak i drugiego.

RF: Jak Pan Profesor ocenia zaskakujaca nieobecność marksizmu na polskich uniwersytetach po 1989 roku?

S. Soldenhoff: Marksizm spotkało to, na co sam zasłużył. Przecież ten nurt od początku, w zamyśle samych twórców, miał być przede wszystkim ideowy, społeczny, dopiero potem akademicki. Miał wiązać się z ideą socjalizmu, służyć ludowi robotniczemu. Stąd ta zmienność 
notowań marksizmu w świecie. Marksizm zawsze wiązano z praktyką polityczną realnego socjalizmu. Dla przykładu, kiedy umacniał się obóz socjalistyczny, zwłaszcza w sektorach militarnych, to notowania marksizmu rosły. Interesowano się nim nawet na Zachodzie. W marksizmie widziano wtedy fragment jakiegoś poważnego przedsięwzięcia, jakiegoś zagrożenia. Po 1989 r., po tym ogólnym krachu, marksizm poszedł na śmietnik. Ale zrobiono to tylko dlatego, ponieważ wiązano go bardzo ściśle z komuna, z socjalizmem w wykonaniu radzieckim. Uważam, że zrobiono to dość lekkomyślnie, dlatego że zawsze widziałem w marksizmie wartościowe elementy. Uważam, że zwłaszcza w filozofii społecznej są takie wątki myślowe, które mogą być bardzo pomocne w zrozumieniu tego, co się dziś dzieje. Niepotrzebnie tak szybko postawiono krzyżyk na marksizmie. On był przecież wielowymiarowy i selektywny. Można było odrzucić wszystko to, co w nim niepoważne, ale zachować to, co wartościowe. Na przykład teoria państwa klasowego, podkreślająca, że państwo zawsze znajduje się w rękach klas posiadających. Czy my dzisiaj tego nie widzimy?! Po wyborach, kiedy wygrała Platforma, słucham dziennika w stacjach: „Euronews” i „BBC” i mówią tam, że w Polsce wygrała partia "probiznesowa”, trzymająca z biznesem. Pojawiły się lamenty różnych socjologów, że trzeba przeciąć związki polityki z biznesem, ale to przecież jest utopia. Jak, na litość boska, można przeciąć te związki, skoro sama instytucja państwa oparta jest na biznesie. Ja myślę, że kapitalizm - tak jak socjalizm - też się wykończy swoimi sprzecznościami.

RF: Jak dzisiaj wyglada dzień Pana Profesora? Jest Pan już na emeryturze, więc na brak czasu chyba nie można narzekać.

S. Soldenhoff: Muszę powiedzieć, że dużo filozofuję, ale tak na swój użytek i zacząłem zwracać uwagę na rzeczy, których nie widziałem, będąc etatowym filozofem. Uważam, że charakter filozofii współczesnej, przez jej nadmierną instytucjonalizację, odciąga człowieka od refleksji i namysłu. Te codzienne obowiązki, zebrania, nie zebrania, pisanina, to odciaga od prawdziwej filozofii, to wszystko wychodzi bokiem. Ja bardzo lubię spokój, bo to mi ułatwia kontakt z przyrodą. Na balkonie mam ptaszki, studiuję albumy, bo właściwie od dziecka to lubiłem. Nie nudzę się. Czytam dużo. Dzięki wykształceniu filozoficznemu mam tę przewagę nad zwykłymi śmiertelnikami, że łatwiej zauważam kłamstwa i manipulacje.

RF: Jak z perspektywy lat ocenitby Pan swoja życiowa droge?

S. Soldenhoff: Żałuję, że nie zostałem leśnikiem. Wtedy byłbym zapewne lepszym filozofem, bo w lesie dobrze się czuję i dobrze mi się myśli. To moje Wprowadzenie do etyki pisałem w Borach Tucholskich. Najlepiej mi się pisało, jak był upał. Robiłem sobie godzinną przerwę, zaraz obok było jezioro i pływałem, albo brałem ponton i zaszywałem się gdzieś koło brzegu w krzakach i tam też sobie pisałem. To jest jed- 
na z rzeczy, jakie pisałem, z której bym się nie wycofał, nawet po tylu latach. Charakterystyki kapitalizmu też bym bronił do ostatniego słowa. Chwaliłem wprawdzie kapitalizm za jego zasługi, ale równocześnie krytykowałem za kult pieniądza, za przecenianie dóbr materialnych, za jednokierunkowe aspiracje. I mówię wam, kapitalizm, który już dzisiaj przekroczył granice swej zachłanności, źle się skończy.

RF: Co mógłby Pan poradzić młodym adeptom filozofii? Przed czym mógtby Pan Profesor przestrzec?

S. Soldenhoff: Strzeżcie się zbytniego angażowania w filozofię instytucjonalna, bo ona pozbawia świeżości myślenia. Od dawna jestem nastawiony do niej bardzo sceptycznie, bo uważam, że ta urzędowość tłumi prawdziwy namysł, to nieustanne wymuszanie publikacji tylko po to, żeby zdobywać jakieś punkty, zaczyna być sztuczne i wymuszone. Bierze się to z czystej pragmatyki: jak nie będziesz miał publikacji, to cię wyleją. Z tego też wynika mój sprzeciw wobec habilitacji. Uważam, że na dobrą sprawę cała procedura jest niemądra, bo ta szumna habilitacja jest tylko powtórzeniem doktoratu. To się $\mathrm{w}$ zasadzie niczym nie różni, jeśli idzie o wartość naukową. A ten proces habilitacyjny jest co najmniej trzy razy bardziej skomplikowany od doktoratu; te tory przeszkód, jakieś tłumy recenzentów, po prostu głupota! Albo wymóg, że trzeba na kolokwium habilitacyjnym pokazać swoje dobre umiejętności jako wykładowca. No przecież całkowity absurd, bo ci, którzy robią habilitację często są wykładowcami od dziesięciu lat! Takim ludziom każe się potem udowadniać, że się nadają na wykładowców.

RF: Widujemy Pana Profesora czasem w Instytucie Filozofii UMK i zastanawia nas jedno: co Pan Profesor czuje dziś, kiedy wchodzi do tego budynku. Nie czuł Pan nigdy słusznej dumy, megalopsychii, jak się wyrażat Arystoteles?

S. Soldenhoff: Jakoś tam specjalnie nie lubię wchodzić, dlaczego? Otóż, zawsze uważałem, że kiedy się człowiek z czegoś wycofuje, to musi za sobą zamykać drzwi i wypadałoby, by robił to konsekwentnie. Bałbym się sytuacji, gdyby ktoś sądził, że ja, jako emeryt, próbuję jeszcze jakoś ingerować w problemy Instytutu, czy wtrącać się w nieswoje sprawy. Dlatego wolałem się odbić od tej firmy i zaglądać od czasu do czasu z pobudek czysto sentymentalnych. A co do jakiejś dumy, to nic z tych rzeczy. Ktoś mnie kiedyś nazwał twórcą ",toruńskiej szkoły etyki”. Przecież ja żadnej szkoły nie stworzyłem. To są komplementy na wyrost. Nie podoba mi się, jak ktoś wynosi mnie na ołtarze. To nie ja.

RF: Nawiazujac do przyrodniczych fascynacji Pana Profesora, to nie bez kozery można wspomnieć Claude Lévi-Strauss'a, który w zaawansowanych latach swojego życia również, z autentycznym przejęciem, mówił o degradacji przyrody. To samo było $z$ Richardem Rorty'm, on bardzo interesowat się ornitologia. Profesor Szahaj podarowat mu nawet atlas ornitologiczny, gdyż ten uwielbiał obserwować ptaki. 
S. Soldenhoff: Ta moja miłość do przyrody jest trochę dziwna, bo ja zostałem wychowany $\mathrm{w}$ duchu, w którym bardzo ceniono sobie polowania. Od dziecka zaszczepiano mi kult myślistwa. Dzisiaj jest to dla mnie barbarzyństwo, zabijanie dla zabawy i ta bezmyślność temu towarzysząca, to mnie przeraża. Niestety musiałem w tym uczestniczyć, za co mam żal do członków mojej rodziny. Wówczas mi się to jednak podobało, jak to szczeniakowi. Nawet do wróbli z procy strzelałem. A teraz? Dzisiaj je dokarmiam na moim balkonie. W pewnym momencie doznałem jakiegoś olśnienia i od razu wszystko się odwróciło. To się stało podczas wojny i od tego czasu zaczęła się moja wielka przyjaźń z przyrodą. Niektóre ptaki, chore lub potwornie zmęczone, przylatują umierać na mój balkon. Oko w tych sprawach mam wyrobione. Czasem przylatują ptaki bardzo napuszone, takie niemrawe, ale dają się łapać, bo wiedza, że nic im nie grozi. Opiekujemy się nimi, czasem tylko dwa lub trzy dni, a potem umierają. I to się powtarza co roku, czasami nawet $\mathrm{w}$ trakcie lata. Coś niesamowitego. Parę tygodni temu córka mówi mi, że dzięcioł leży na balkonie. To był zielony dzięcioł, którego w tych rejonach często się nie spotyka. Skąd się tu wziął? Dlaczego akurat tu, na moim balkonie? Co ciekawe, nie miał żadnych obrażeń, umarł ze starości. To są właściwie rzeczy, które prowadzą do metafizyki. Mam też koty, o tego czarnulka. Koty są niezwykle interesujące, obrażają się, mają swoją osobowość. Mówię wam, najwięcej tajemnic jest pod ręką. Niech się wypchają z astrologia, horoskopami i bajdurzeniem o duchach. 